\title{
Machinery production networks in Latin America: a quantity and quality analysis
}

\author{
Mateus Silva Chang ${ }^{1}$
}

Received: 18 October 2016/Revised: 28 July 2017/Accepted: 25 October 2017/

Published online: 13 November 2017

(C) The Author(s) 2017. This article is an open access publication

\begin{abstract}
This paper investigates the effects that the increase in the importation of machinery parts and components and the changes in the supplier composition had in the trade of final products and parts and components inside Latin America. In our analysis, we consider these effects according to two dimensions: a quantity one that captures whether there was an intensification of trade and a quality one that captures changes in the sophistication of the traded goods. The research employs disaggregated trade data obtained from UN Comtrade for 17 Latin American countries between 1996 and 2011. We find evidence that an increase in the importation of parts and components from Latin America had positive impacts on both the quantity and quality dimensions. Subregional heterogeneities revealed that, in general, imports from East Asia had positive effects on the quantity dimension, nurturing the expansion of machinery production networks inside Latin America, and on the quality dimension, increasing the sophistication of the products traded inside Latin America, especially for Mercosur member exports. Imports from North America had positive quantity effects, especially for exports of countries from the Andean Community, Central America, Chile, and Mexico.
\end{abstract}

Keywords Machinery trade $\cdot$ Fragmentation - International production networks · Latin America

JEL Classification F14 $\cdot$ F15 $\cdot$ F23

Mateus Silva Chang

mateus.chang@keio.jp

1 Graduate School of Economics, Keio University, 2-15-45 Mita, Minato-ku, Tokyo 108-8345, Japan 


\section{Introduction}

In the past few decades international trade has increased exponentially and production fragmentation was one of the main causes. The fragmentation process, referred as "trade in tasks" by Grossman and Rossi-Hansberg (2008), has led to an increase in global integration, generating a web of economic interactions commonly denoted as international production networks. In the beginning, this change involved mostly trade among rich nations, but the real "revolution started when supply chain trade gained importance among high-tech and low-wage nations between 1985 and 1995" (Baldwin and Lopez-Gonzalez 2015). Production fragmentation opened new possibilities of economic growth to developing countries, allowing their engagement in the production process of manufactured goods that they were not able to produce.

The expansion of production networks changed the rules of the economic development game, facilitating developing countries' access to networks, global markets, capital, knowledge, and technology (OECD 2013). Previously, a country had to climb every single step in the industrial development ladder, mastering all production processes, to manufacture a given good. However, the advent of production networks offered the possibility of skipping steps in the catch-up procedure through the acquisition of knowledge and technology from third countries and the specialization in one or few steps of the production process. Understanding these changes and their consequent implications is crucial to draw policies that integrate a country in this new production structure and allow it to explore the best possibilities for guaranteeing sustainable economic growth and development.

The empirical literature about production fragmentation is very rich, with many studies focusing on the regions where production fragmentation is more developed: East Asia, the European Union, and North America. ${ }^{1}$ Although the demand is growing for the analysis of the current situation and the effects that this new trend can have on Latin America, the literature is still incipient.

A few papers provide some information about the status of production fragmentation in Latin America based on descriptive analysis. Aminian et al. (2009) compared the economic integration process in East Asia and Latin America, analyzing the characteristics and intensity of intra-bloc and inter-bloc trade. They used a revealed comparative advantage (RCA) index to identify the share of traded manufacture parts and components with comparative advantage in the intra-bloc trade. Curran and Zignago (2013) studied the regionalization of trade in South America from 1994 to 2007, differentiating the trade flows by the end use of the products and the level of embodied technology. They concluded that the trade agreements have not extensively affected the regional trade level and that trade of intermediate products was still very low, indicating that regional production networks were still under-developed. Calfat et al. (2011) investigated the participation of Argentina, Brazil, Guatemala, and Nicaragua in fragmented world

\footnotetext{
${ }^{1}$ For papers on production networks in the mentioned regions please refer to $\mathrm{Ng}$ and Yeats (2003), Ando and Kimura (2005), Athukorala and Yamashita (2006), Kimura et al. (2007), Yokota (2008), Kohpaiboon and Yamashita (2011), Ando and Kimura (2013a) and Ando and Kimura (2013b).
} 
production. They concluded that Brazil was the only country with a consolidated participation in fragmented production. Fung et al. (2015a) used manufacturing trade data, classified according to the Standard International Trade Classification (SITC), to compare production sharing in Latin America, North America, and East Asia from 1985 to 2006. They identified the existence of a relatively thick production network involving the trade of parts of motor vehicles, telecommunication equipment, and electronic components. However, it was concentrated on Mexico's trade with US and Canada, while Brazil also played a smaller role. Fung et al. (2015b) used the same data and methodology to compare Brazil, China, and Mexico's participation in production networks. They analyzed the international trade patterns for the period 1990-2010, identifying that China's global presence in the trade of parts and components increased. Although Mexico concentrated its trade of parts and components with the US, the data showed that China has become a major source of parts and components to Mexico and Brazil. The authors highlight the increasing importance of a Pan-Pacific link and a possible creation of a ChinaBrazil-Mexico production network.

Florensa et al. (2015) produced the first paper that used a quantitative framework to analyze economic integration and production fragmentation in Latin America. Using trade data classified according to the Broad Economic Categories (BEC), the authors analyzed the impact that changes in import of intermediate goods from different world regions had in the development of Latin America's regional trade. They found evidence of increasing regional production networks and the importance of other regions as suppliers of intermediate products, with special attention on China.

Given the importance of this topic to the development literature and that production networks in Latin America are still understudied, this work contributes to the literature shedding light on the evolution of Latin American machinery industry. The first reason to focus on this industry is that machinery final products have a high level of complexity and use of a large number of parts and components, being the most developed manufacturing industry in terms of production fragmentation. Consequently, when the industry is more fragmented, a country will have more opportunities to engage in the production network. The second reason is that the high level of fragmentation and the availability of disaggregated trade data allow us to classify this industry into four different sectors. This division permits the development of a finer correspondence between parts and components and final products for a specific sector, reducing the bias that more aggregated data can generate. Finally, the share of machinery in Latin American exports and imports of manufactured products in 1996 was approximately 49.5 and $55.8 \%$, respectively, while in 2011, the shares increased to 55.5 and $56.7 \%$, respectively. Therefore, machinery is the most important industry in the region's manufacturing trade. ${ }^{2}$

The contribution of this article is threefold. First, to the best of our knowledge, this is the first article to analyze the quality effects that the changes in the structural composition of suppliers of parts and components have had in the development of

\footnotetext{
${ }^{2}$ The shares were calculated based on the harmonized system (HS) classification. The manufactured goods range from HS 28 to HS 92, while machinery products range from HS 84 to HS 92 .
} 
regional machinery production networks in Latin America. Second, different from the previous papers on Latin American production networks that use aggregated intermediate manufacture data, we focus our analysis on a specific industry and use disaggregated data. Third, in this paper we adopt a model similar to Florensa et al. (2015), but estimate it using the PPML method instead of the ordinary least squares (OLS) to control the zero trade values and the data heteroscedasticity.

The study is organized as follows. Section 2 includes a descriptive analysis of Latin America's participation in the machinery trade. In Sect. 3, we present the data and in Sect. 4 we describe the empirical methodology employed. Section 5 shows the results of the quantity analysis, while Sect. 6 contains the results for the quality analysis. The final considerations of the paper are available in Sect. 7.

\section{Machinery international trade and Latin America}

In this section, we used trade data-classified according to the Harmonized System (HS) disaggregated to the six-digit level-to analyze the machinery international market and Latin America's participation in it in 1996 and 2011. We also considered the changes in trade patterns from a trade margin and product sophistication perspective to identify modifications in Latin American countries' trade basket composition.

\subsection{Descriptive analysis: traded values}

Production networks, in particular the machinery ones, are constituted mainly of geographical agglomerations that form regional blocs of production. Three main regional blocs are recognized for machinery production: the East Asian region, the European Union, and NAFTA. In general, machinery trade studies focus on these main areas, ignoring the situation in Latin America and the rest of the world. The main reason for this fact is illustrated by Fig. 1, which shows the data for world imports and exports of machinery. The aforementioned main areas are responsible for the bulk of the traded values, while Latin America and the rest of the world are responsible for a very small share. ${ }^{3}$ Another important difference is that the traded value of parts and components is larger than the final product in the three main regions, while in Latin America, the traded value of the final product is higher. This evidence suggests a lower engagement of Latin America in machinery production networks.

The idiosyncrasies of Latin America, a heterogeneous region composed of countries of different sizes and governments with different political and economic orientation, localized in a vast territory full of geographical barriers, such as the Andes Mountains and the Amazon Forest, are possible reasons for its low level of engagement in production networks. Another reason, identified by Moreira et al.

\footnotetext{
3 The figures and table in this subsection present a conservative estimate of the situation in Latin America, given that Mexico trade data are accounted for in the NAFTA region. From the next subsection on, Mexico's data will be considered as part of Latin America.
} 


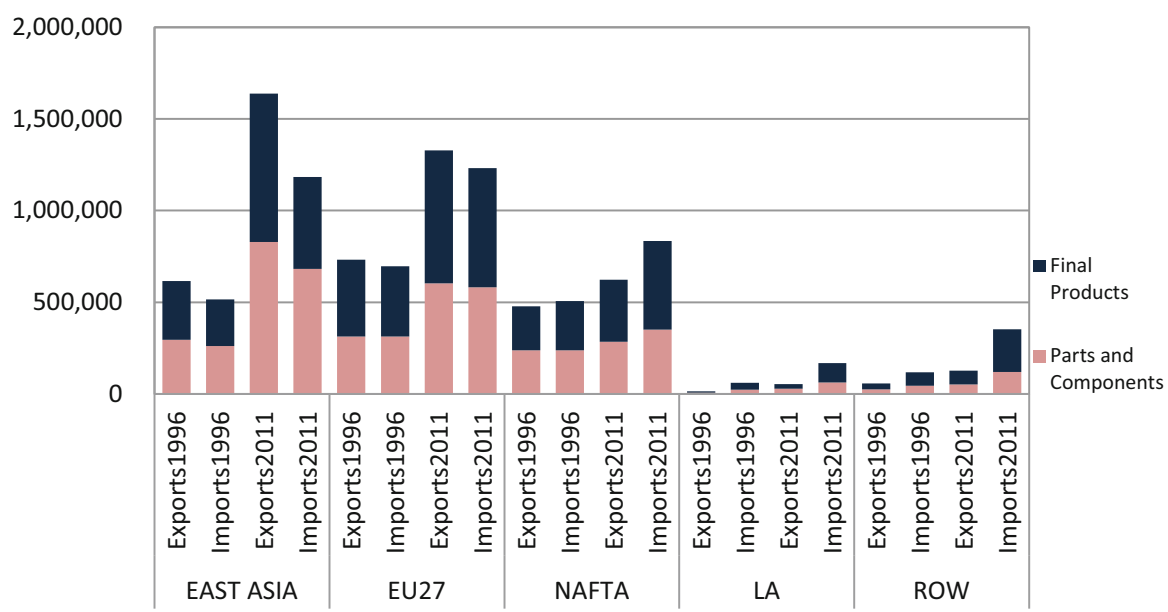

Fig. 1 Total values of exports and imports per region in 1996 and 2011 (in million US\$). Source Chang and Kimura (2015)

(2013), is the quality of the local infrastructure that penalizes the trade, increasing the freight costs or simply making it impracticable at competitive prices.

Nevertheless, Fig. 2 reveals that for the period 1996-2011 parts and components traded value increased relative to final products. Latin American export data show an increase in traded parts and components from 46.6 percentage points to 54.4 percentage points. Although import data reveal an increase in traded parts and components share of just 0.5 percentage points, in terms of values this change represents a substantial increase, given that imported machinery parts and components value is higher than the exported machinery total value. Even though traded values are still smaller than the three main blocs, the increase in import of parts and components indicate that Latin America is slowly adhering to production networks in the machinery industry. Table 1 displays the compound annual growth rate of the machinery trade, revealing that Latin America had the highest growth rate for total machinery export and the second highest for machinery import. In fact, considering just the trade of parts and components, the region had the highest growth rates, corroborating the idea that participation in machinery production networks is growing in this region.

According to fragmentation theory, the core of a production network is concentrated in regional agglomerations, given the reduced costs incurred in shorter distance transport freights, reduced lead time, and the possibility of faster coordination for the whole network (Harrigan and Venables 2004; Kimura et al. 2007). Nonetheless, the development of the internet and other communication and coordination technologies, as well as the decrease in freight cost, has led to a decrease in the service link costs (Jones and Kierzkowski 2005), allowing for a growth in interactions between regional blocs. As a result, the East Asian region increased its role as a supplier of machinery parts and components to other region's production networks. Bearing this fact in mind, in Fig. 3 we observe the 


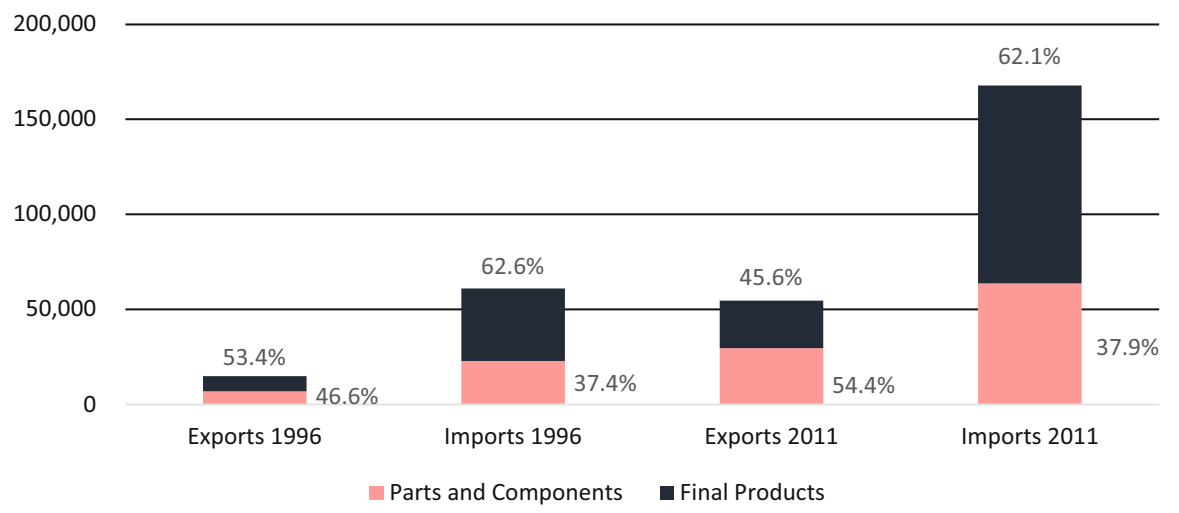

Fig. 2 Latin America's total value of machinery products trade in 1996 and 2011 (in million US\$). Source Author's calculation, using data available from the UN Comtrade

Table 1 Compound annual growth rate of machinery trade from 1996 to 2011

\begin{tabular}{lcll}
\hline & Parts and components (\%) & Final products (\%) & Total (\%) \\
\hline East Asia & & & \\
Exports & 7.1 & 6.4 & 6.7 \\
Imports & 6.6 & 4.6 & 5.7 \\
EU & & & \\
Exports & 4.5 & 3.7 & 4.1 \\
Imports & 4.2 & 3.6 & 3.9 \\
NAFTA & & & \\
Exports & 1.2 & 2.3 & 1.8 \\
Imports & 2.6 & 4.0 & 3.4 \\
LA & & & $\mathbf{9 . 0}$ \\
Exports & $\mathbf{1 0 . 1}$ & $\mathbf{7 . 9}$ & 7.0 \\
Imports & $\mathbf{7 . 1}$ & 6.9 & 5.4 \\
ROW & & & 7.6 \\
Exports & 5.1 & 5.7 & \\
Imports & 6.9 & $\mathbf{7 . 9}$ & \\
\hline
\end{tabular}

The higher compound annual growth rates are highlighted using bold text Source Author's calculation, using data available from the UN Comtrade

composition of parts and components suppliers for all five regions to verify changes and patterns. As expected, except for NAFTA in 2011, the intra-bloc import of machinery parts and components is dominant in the three main regions. We also verify an increase of the East Asian share in all regions. Data for Latin America reveal a few things: first, the Latin American share as a supplier is irrelevant in all regions except Latin America; second, its intra-bloc share is smaller than the shares of the three main regions; and third, NAFTA and European Union shares decreased 


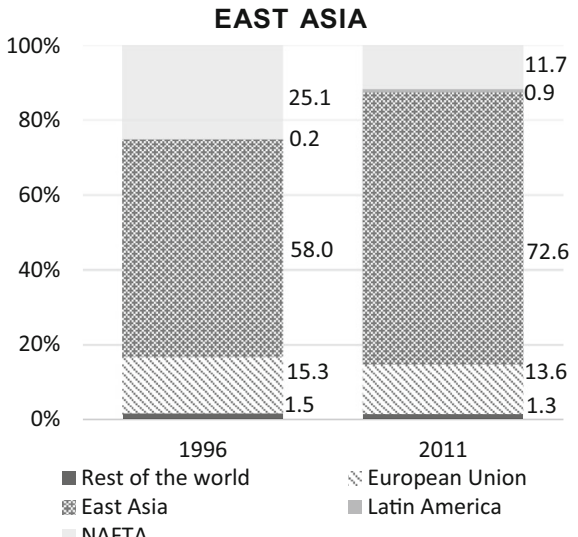

NAFTA

$100 \%$

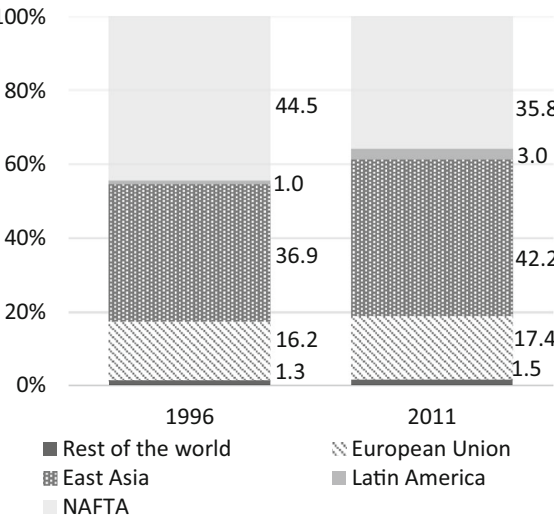

EUROPEAN UNION

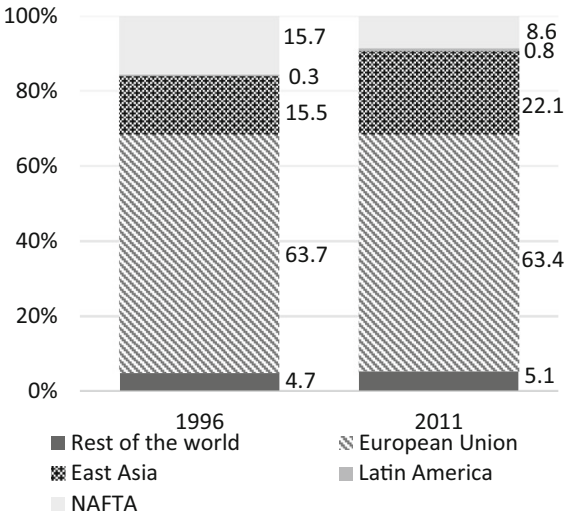

LATIN AMERICA

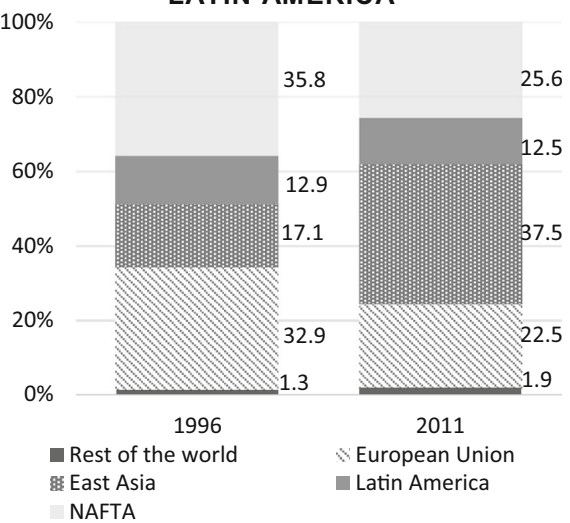

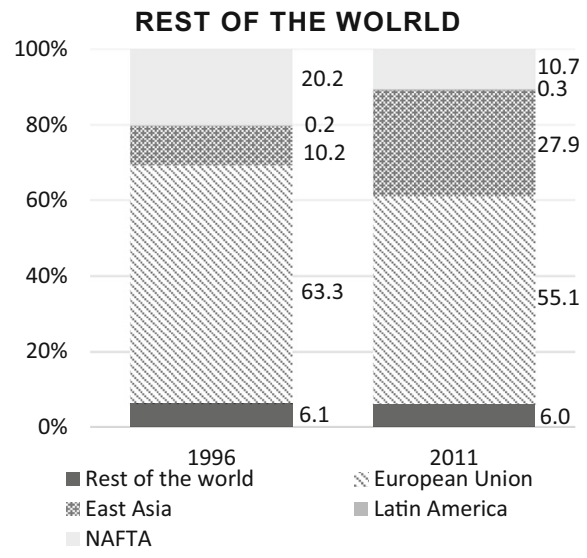

Fig. 3 Composition of suppliers of machinery parts and components in 1996 and 2011. Source Author's calculation, using data available from the UN Comtrade 
considerably, substituted mainly by imports from East Asia. In fact, Latin America was the region where the share of East Asian parts and components increased the most, a growth of more than 20 percentage points.

From the perspective of production fragmentation logic, a country purchases more parts and components from a given region if these products have some comparative advantage. The existing literature highlights two channels through which access to inputs can benefit a country: an efficiency gain in the production process by the acquisition of cheaper and/or higher quality inputs (Amiti and Konings 2007; Goldberg et al. 2010) and the possibility of having access to inputs that previously could not be produced domestically or obtained from a third country (Goldberg et al. 2009). In both cases, a gain in productivity and changes in production pattern are expected. Based on this fact, we consider the hypothesis that the increase in import of parts and components, especially from East Asia, should be beneficial to Latin American machinery production networks.

In the next subsection, we analyze the trade margins to identify possible trade pattern modifications.

\subsection{Descriptive analysis: the trade margins approach}

The trade flow can be decomposed in extensive and intensive margins, revealing how the intensification of trade in existing relations and the beginning or ending of trade relations contribute to change this flow. Although the intensive margin is expected to be the main factor responsible for the changes, authors such as Hummels and Klenow (2005) and Kehoe and Ruhl (2013) identified that in situations of considerable trade growth the extensive margin contribution is also relevant. Our main interest in observing the extensive margins is to identify evidence of changes in Latin American countries' import and export baskets.

A country's trade relation is understood as a product-destination pair in the case of exports and a product-supplier pair in the case of imports. Given an initial and a final period, if a pair is active in both periods it is classified as a continuing pair. If country A imported (exported) a given product from (to) country B in the first period and then does not in the second period, but it still imports (exports) the product in question from (to) a third country, we have an exit of supplier (destination). If a similar situation occurs, but in the second period the product in question is not imported (exported) from (to) any other country, then it is classified as an exit of product. If in the second period, country A imports (exports) a product that was not imported (exported) from (to) any other country in the first period, then this new relation is classified as an enter of product. If in the second period, country A starts to import (export) from (to) country B a product that was already imported (exported) in the first period from (to) a third country, then this new relation is classified as an entry of supplier (destination).

Considering only the number of relations, Fig. 4 illustrates the margins of each Latin American country import of machinery parts and components. Mexico and Brazil had the highest number of product-supplier active pairs in 2011, while El Salvador, Honduras, Nicaragua and Paraguay had the lowest number of active pairs. The data reflect the diversification of the industrial park in each country. The entry 


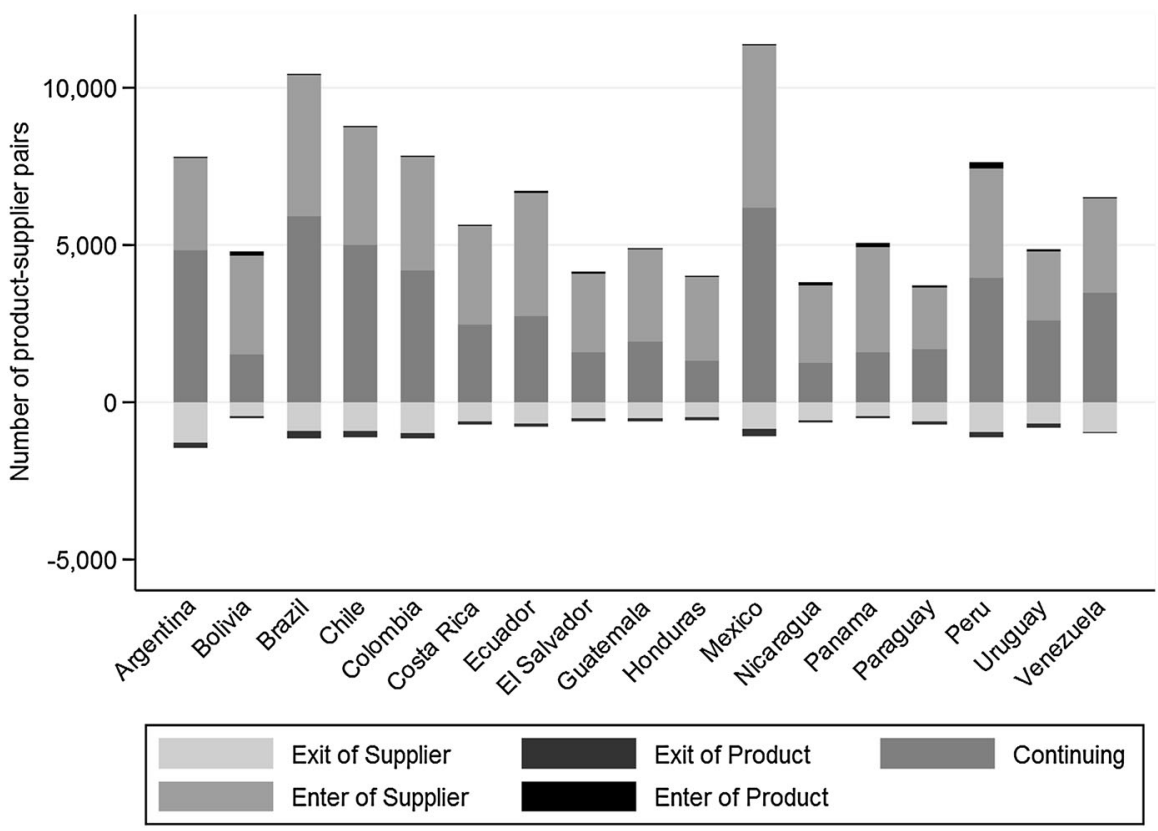

Fig. 4 Number of product-supplier pairs in machinery parts and components imports according to the trade margins from 1996 to 2011. Source Author's calculation, using data available from the UN Comtrade

of supplier margin had a very important contribution in all cases, signaling an increasing integration of Latin America in the international economy.

Following Obashi and Kimura (2016), we identify the contribution that each margin had in the trade growth. To calculate these contributions, we use the following methodology:

$$
\begin{aligned}
& \frac{\sum_{i} x_{i, t_{1}}^{c}-\sum_{i} x_{i, t_{0}}^{c}}{\sum_{i} x_{i, t_{0}}^{c}}=\frac{\sum_{i \in I^{c}}\left(x_{i, t_{1}}^{c}-x_{i, t_{0}}^{c}\right)}{\sum_{i} x_{i, t_{0}}^{c}}+\frac{\sum_{i \in \mathrm{ENP}^{c}} x_{i, t_{1}}^{c}}{\sum_{i} x_{i, t_{0}}^{c}}+\frac{\sum_{i \in \mathrm{ENC}^{c}} x_{i, t_{1}}^{c}}{\sum_{i} x_{i, t_{0}}^{c}} \\
& -\frac{\sum_{i \in \mathrm{EXP}^{c}} x_{i, t_{0}}^{c}}{\sum_{i} x_{i, t_{0}}^{c}}-\frac{\sum_{i \in \mathrm{EXC}^{c}} x_{i, t_{0}}^{c}}{\sum_{i} x_{i, t_{0}}^{c}}
\end{aligned}
$$

where the value of a country $c$ 's trade flow $x$ for product-country pair $i$ in period $t$ is denoted as $x_{i, t}^{c}, I^{c}$ are the continuing pairs, $\mathrm{ENP}^{c}$ are the entering products, $\mathrm{ENC}^{c}$ are the entering countries, $\mathrm{EXP}^{c}$ are the exiting products, and $\mathrm{EXC}^{c}$ are the exiting countries.

Figure 5 confirms that the most important contribution is the intensive margin. Even though the supplier entry contribution is not as big as in the previous figure, it still accounted for an important portion of the parts and components import growth, indicating that the Latin American countries increased their diversity of parts and components suppliers. 


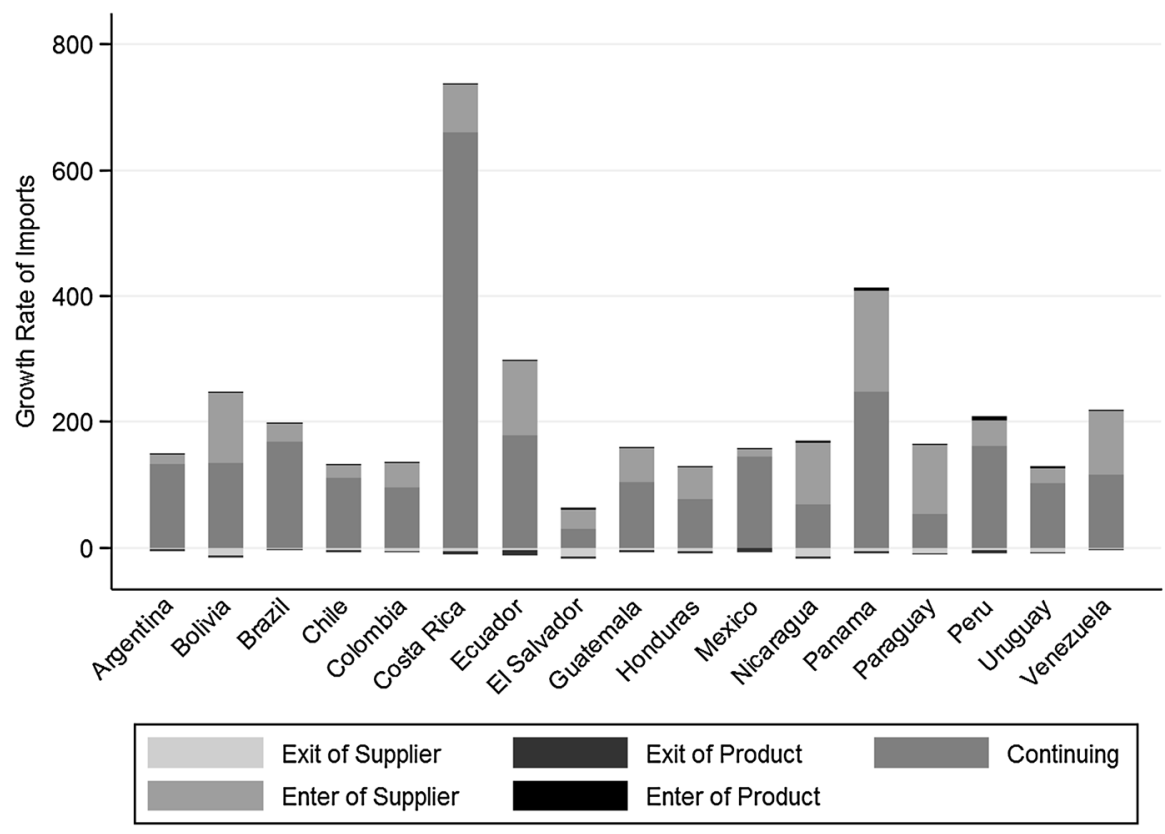

Fig. 5 Decomposition of growth in machinery parts and components imports according to the trade margins from 1996 to 2011 (\%). Source Author's calculation, using data available from the UN Comtrade

We also observe the contribution of the extensive and intensive margins in Latin American countries exports to verify if there were changes in the variety of exported products and destinations. Figure 6 shows the export margins considering only the numbers of product-destination pairs. Once again, the entry of new destinations and the continuation of existing pairs are important margins. However, this time the entry of new products is also important, indicating a change in the exported goods variety. Argentina, Brazil, and Mexico already had a more developed industrial park in 1996; consequently, their entry of products is very small. Another interesting feature is that in some cases the exit of products and destinations is large, also indicating a change in the export basket composition.

Next, we decompose the export growth according to its respective margins. Figure 7 reveals different patterns. The growth in countries with more developed industrial parks such as Argentina, Brazil, and Mexico focused on the intensive margin (Honduras is an exception, having a similar pattern to these countries). The entry of new products was an important margin in countries such as Ecuador, Nicaragua, Paraguay, and Uruguay, while in other cases, the entry of new productdestination pairs was more important. In countries such as Bolivia, El Salvador, Peru, and Venezuela, the exit of products and destinations had an important role, showing an export basket specialization tendency.

The previous figures offer evidence that the pattern of Latin American countries' imports and exports changed during the studied period. We performed one additional exercise to identify changes in the number of machinery products traded 

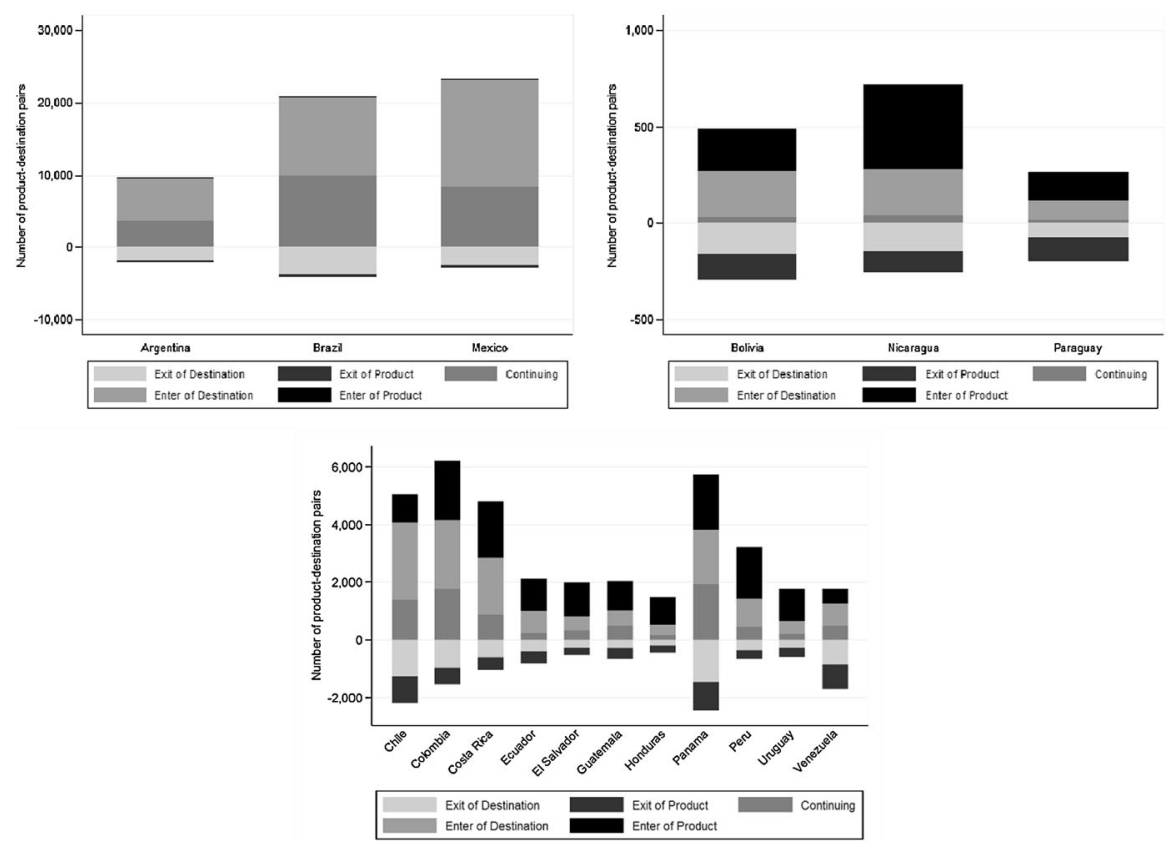

Fig. 6 Number of product-destination pairs in machinery exports according to the trade margins from 1996 to 2011. Source Author's calculation, using data available from the UN Comtrade
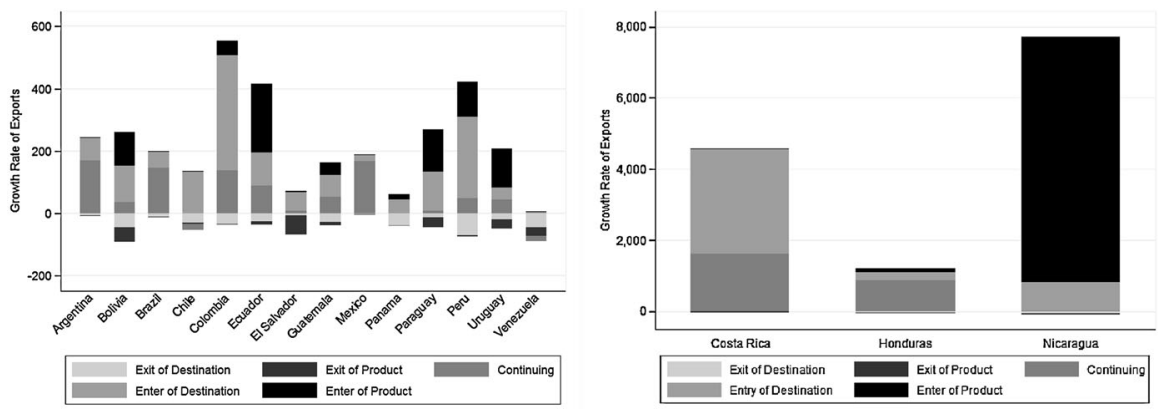

Fig. 7 Decomposition of growth in machinery parts and components exports according to the trade margins from 1996 to 2011 (\%). Source Author's calculation, using data available from the UN Comtrade

by country pair. $^{4}$ The upper part of Fig. 8 shows an increase in the variety of parts and components and final products imported. The main changes are attributed to an increase in products traded with China. The lower part of Fig. 8 reveals a predominant increase in the variety of exports to Latin American countries,

\footnotetext{
${ }^{4}$ Given the economic growth of China after the WTO accession in 2001, we consider the importance of disentangling the impacts of this country from the rest of the East Asian region. We separate the East Asian region into two groups: a first group composed only of China and Hong Kong (hereafter referred to as China), and a second group composed of the other countries in the region that we address as East Asia (EA). As mentioned before, after this subsection we consider Mexico as a member of Latin America.
} 

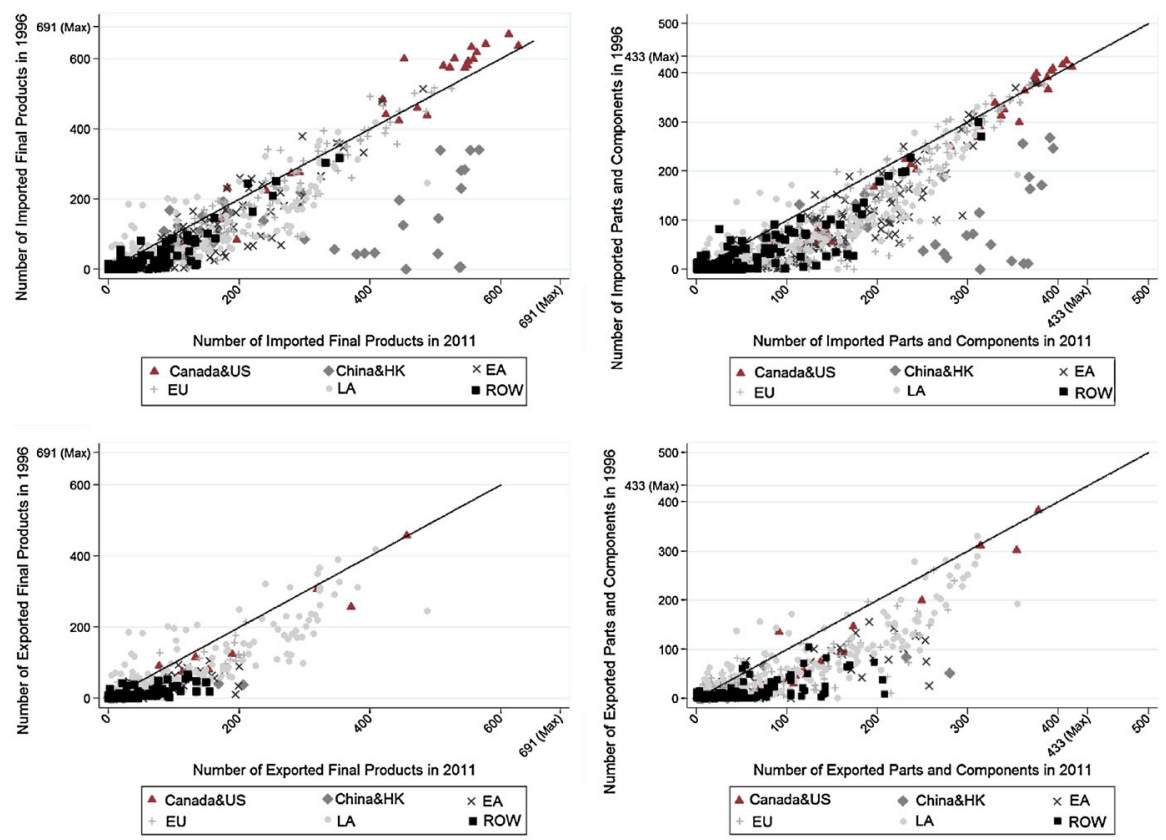

Fig. 8 Number of machinery products traded by country according to their region. There are a total of 433 machinery parts and components and 691 machinery final products. Source Author's calculation, using data available from the UN Comtrade

followed by an increase in the variety of parts and components exported to other regions.

Given the evidence of change in the import and export pattern of Latin American countries, in the next subsection we analyze the changes on traded products quality.

\subsection{Descriptive analysis: sophistication level}

Concomitant to the increase in Latin America's machinery trade flow and changes in the structural composition of machinery parts and components suppliers, a modification in the trade basket composition is expected. To evaluate this change, we used the PRODY index ${ }^{5}$ developed in Hausmann et al. (2007). According to the authors, the PRODY "index is a weighted average of the per capita GDP of countries exporting a given product, and thus represents the income level associated with that product". In other words, this index attributes to each one of the products a value that varies according to the share and per capita GDP of the countries that export it. This result means that products with higher PRODY values were exported more by developed countries, while products with lower PRODY values were

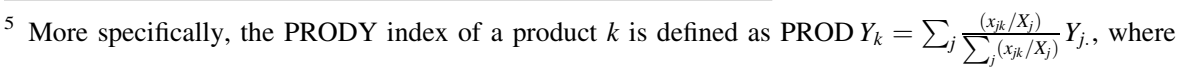
$x_{j k} / X_{j}$ is the value-share of the commodity $k$ in the country $j$ 's overall export basket; $\sum_{j}\left(x_{j k} / X_{j}\right)$ is the aggregated value-shares across all countries exporting good $k$.
} 
Table 2 Summary statistics of the PRODY index by products aggregation

\begin{tabular}{lllllll}
\hline Products aggregation & Mean & Median & SD & Min & Max & Observations \\
\hline All goods & $14,171.7$ & $14,076.5$ & 6110.3 & 747.7 & $46,860.5$ & 5023 \\
Non-manufactured goods & $11,670.5$ & $10,999.9$ & 6191.0 & 747.7 & $32,835.9$ & 1022 \\
Manufactured goods & $13,896.5$ & $13,446.5$ & 6097.1 & 809.5 & $46,860.5$ & 2877 \\
Machinery goods & $17,150.3$ & $17,289.3$ & 4705.8 & 3730.2 & $35,433.8$ & 1124 \\
\hline
\end{tabular}

Source Author's calculation, using data available from Hausmann et al. (2007)

exported more by developing countries. The PRODY index can be used as a proxy for the sophistication of the product.

Table 2 contains the PRODY index summary statistics for all products according to the HS classification disaggregated to the six-digit level. The index varies from 747.7 to $46,860.5$, and the mean is $14,171.7$. Although the index represents the income level associated with a given product, it is hard to attribute a sense of cardinality, making it easier to interpret as an ordinal index. In the lower part of the table, the products were classified into three different categories. ${ }^{6}$ We observe that non-manufactured products have the lowest PRODY index mean, while machinery products have the highest. Additionally, the standard deviation of the machinery goods PRODY index is the lowest, indicating that, in general, the products of this category are more sophisticated than the others.

Next, we use the PRODY index to calculate the sophistication of the parts and components import basket and the intra-bloc export basket. The objective is to verify if changes in the parts and components import pattern led to changes in the pattern of the Latin American intra-bloc trade. Figure 9 reveals that for six countries the average sophistication degree of their machinery parts and components imports decreased, while the rest experienced an increase in the sophistication level. Figure 10 illustrates the changes in the sophistication of the intra-regional export basket. We observed a decrease in the sophistication level of the final products export basket for seven countries, while the same occurs for just five countries in the parts and components export basket case. Although the results are not homogeneous, we verify gains in the export basket sophistication for the majority of the countries.

\subsection{Descriptive analysis: machinery sector data}

According to previous studies on machinery production networks, the machinery industry can be classified into four different sectors: general machinery, electric machinery, transport equipment, and precision machinery. Based on this classification, Fig. 11 reveals Latin America's machinery parts and components imports by sector. We observe that electric parts and components had the biggest share in both

\footnotetext{
${ }^{6}$ Non-manufactured goods are the products classified from HS 1 to HS 27 and HS 93 to HS 99; manufactured goods are the products from HS 28 to HS 83, and machinery includes the products from HS 84 to HS 92 .
} 

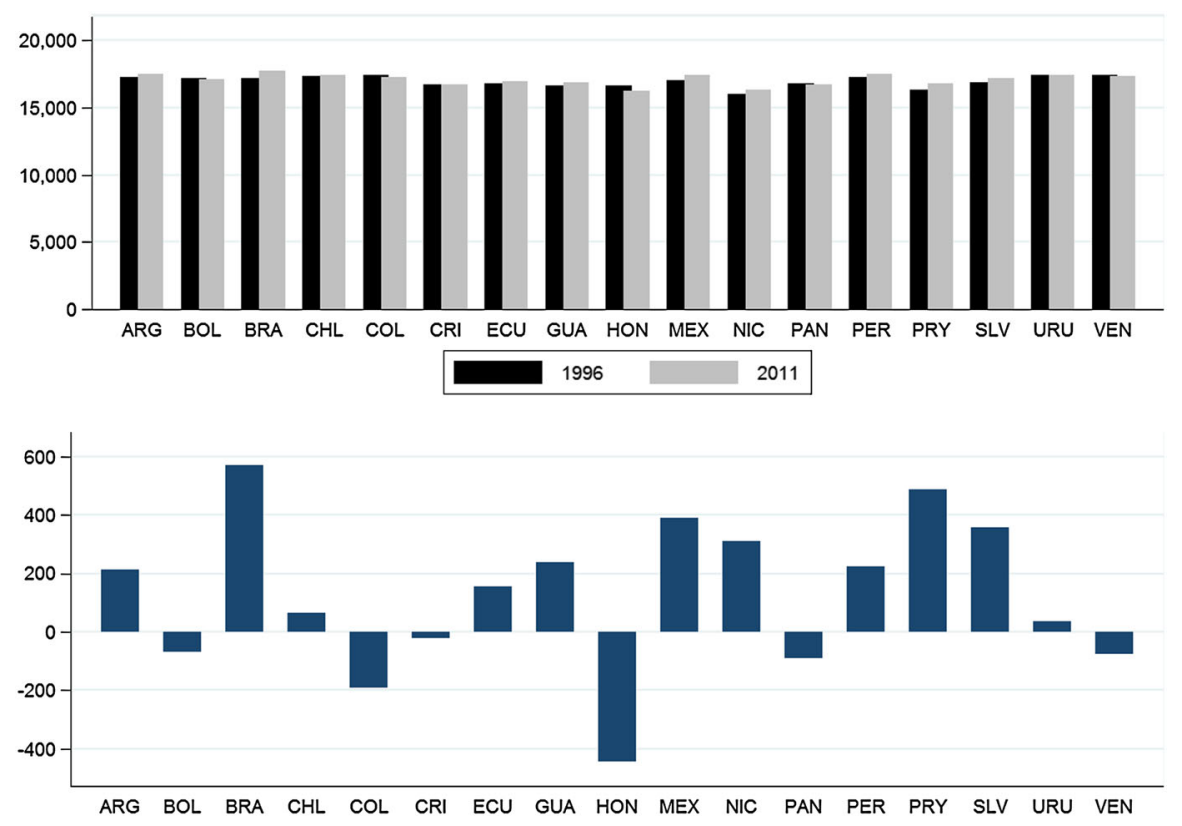

Fig. 9 Average sophistication level of the machinery parts and components import basket. Source Author's calculation, using data available from the UN Comtrade
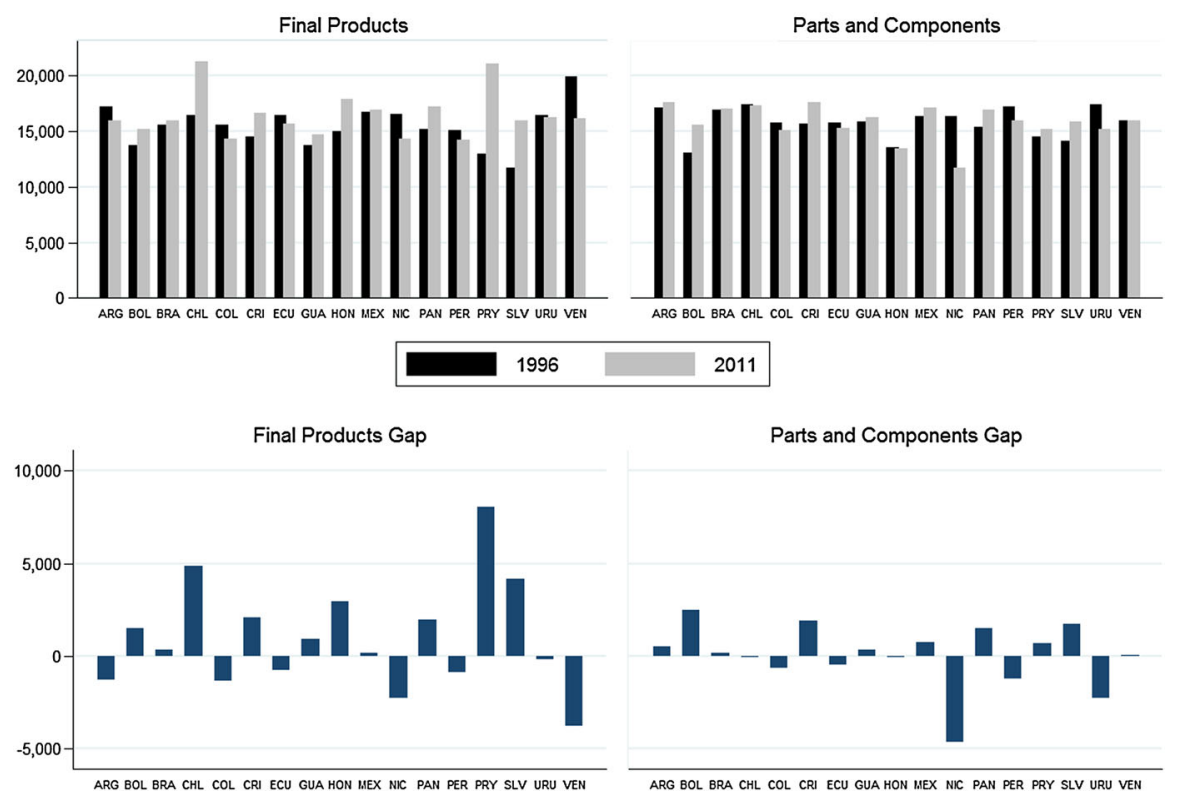

Fig. 10 Average sophistication level of the machinery parts and components and final products export basket. Source Author's calculation, using data available from the UN Comtrade 


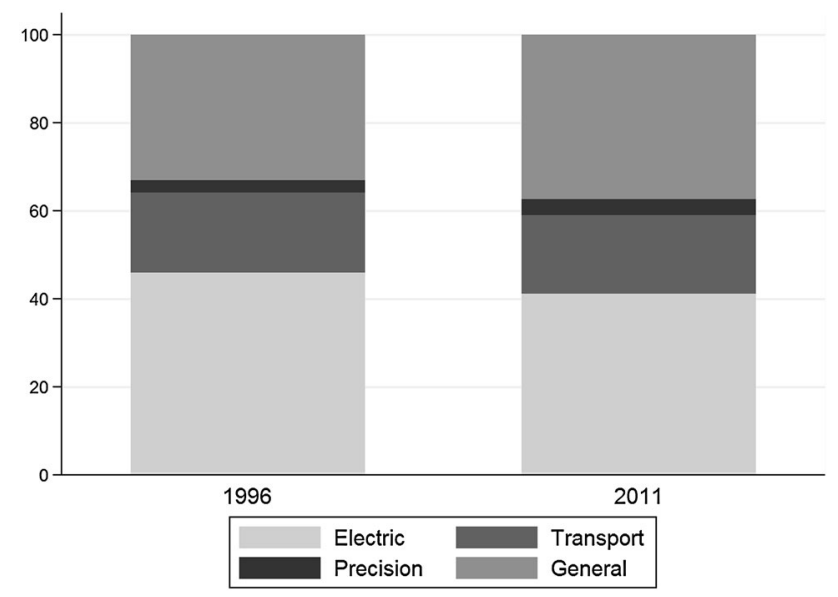

Fig. 11 Latin America machinery parts and components import composition by sector in 1996 and 2011. Source Author's calculation, using data available from the UN Comtrade
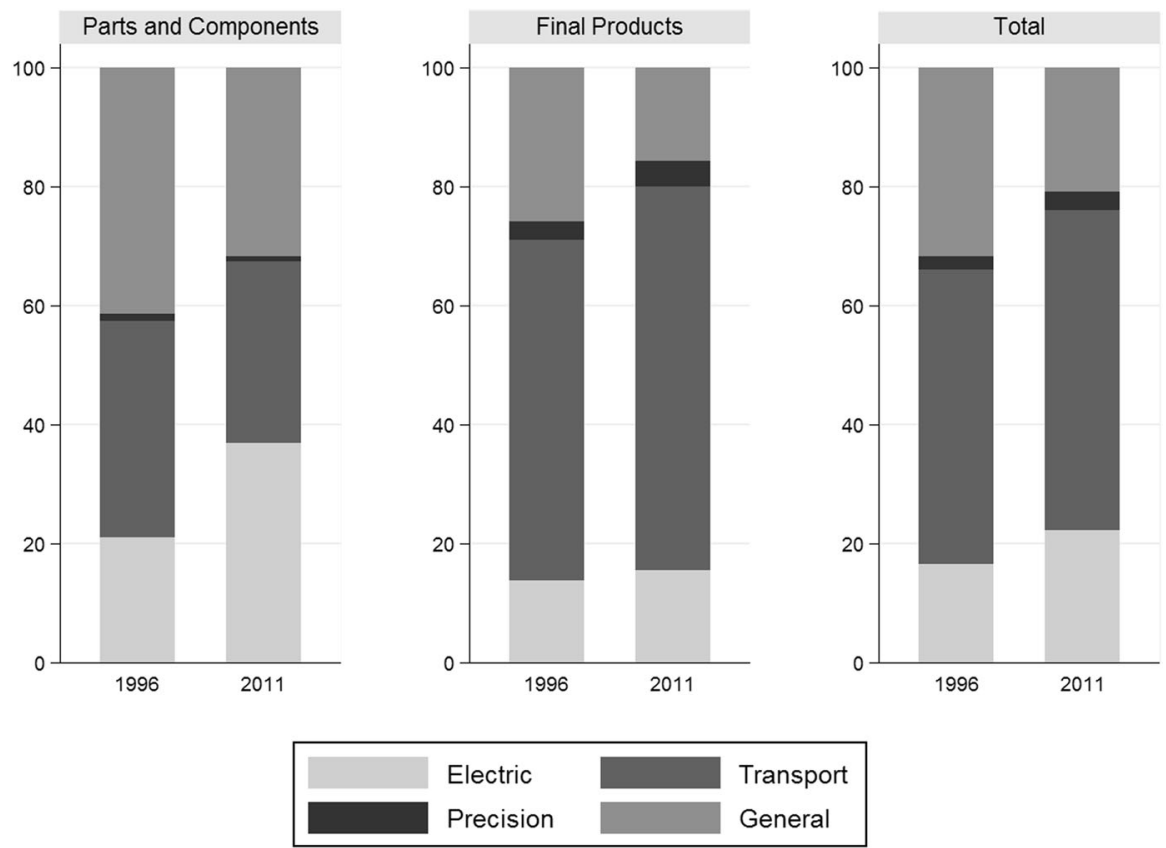

Fig. 12 Latin America machinery export composition by sector in 1996 and 2011. Source Author's calculation, using data available from the UN Comtrade

years, although it declines in 2011. General machinery had the second biggest share, followed by transport equipment. Figure 12 plots the share of each sector in regional exports of final products and parts and components. Despite the observed increase in the share of general machinery imports, regional exports were focused mainly in 
transport equipment. From 1996 to 2011 we identify a change in the final products export pattern with electric machinery achieving the second biggest share. A similar movement occurred for the case of parts and components exports. Observing the total exports share, we identify that transport equipment products were the most exported ones inside Latin America, while electric machinery became the second most traded in 2011. Based on the importance of these two sectors and that the study of their heterogeneity be a common practice in the literature, we also investigate them independently.

In view of the facts presented in this section, the change in Latin America's machinery trade pattern, the increase in trade flows and the modification in the average sophistication level of the traded products, in the next sections, we present the data and methodology employed to study the effects that changes in the structural composition of machinery parts and components suppliers had in the expansion of Latin American production networks and in the sophistication of the intra-bloc export basket.

\section{Data}

In the economics literature, many studies have been conducted on the fragmentation of production with different ways of defining the object of study. Some scholars employ a more comprehensive definition of production networks, including in their analysis all inputs used, from the raw materials to the final product. To capture all production steps they use international input-output tables. ${ }^{7}$ On the other hand, some scholars do not consider the raw materials in their analysis, understanding that just the trade of parts and components used in a given industry should be analyzed. This second group of researchers adopt a more refined classification to isolate parts and components from final products. ${ }^{8}$

We embrace the second view for two reasons: no international input-output data are available for the majority of the Latin American countries, and the second definition permits the use of more disaggregated and specific data. Considering that the machinery industry presents a high level of complexity and uses a large number of parts and components, we adopted this industry as our object of study.

The analysis of machinery production networks was based on the classification of the machinery trade in parts and components and final products. ${ }^{9}$ The data used was collected from the United Nations Commodity Trade Statistics Database (UN Comtrade), classified according to the HS disaggregated to the six-digit level. The machinery industry comprises all the goods categorized as general machinery sector

\footnotetext{
7 For example, Timmer et al. (2015) used the World Input-Output Database (WIOD), while Baldwin and Lopez-Gonzalez (2015) employed WIOD and OECD-WTO TiVA data to analyze production networks.

${ }^{8}$ For example, Athukorala (2005) separates manufacturing parts and components from final products using the SITC data, while Ando and Kimura (2005) do the same for the machinery industry using HS data.

9 This process was performed in accordance with the classification presented in Ando and Kimura (2005).
} 
(HS84), electric machinery sector (HS85), transport equipment sector (HS86-89), and precision machinery sector (HS90-92).

We consider the import of parts and components from countries that were responsible for at least $0.01 \%$ of the international machinery trade in 2011. The selected 89 countries are grouped in six regions. ${ }^{10} \mathrm{We}$ define Latin America as the group of 17 countries consisting of Argentina, Bolivia, Brazil, Chile, Colombia, Costa Rica, Ecuador, El Salvador, Guatemala, Honduras, Mexico, Nicaragua, Panama, Paraguay, Peru, Uruguay, and Venezuela.

The PRODY measure was employed as the qualitative measure for the export and import basket of Latin American countries. ${ }^{11} \mathrm{We}$ also used tariff data and the depth of the Preferential Trade Agreements (PTA) ${ }^{12}$ to account for the level of integration of the Latin American economies. The tariff data were collected from the World Integrated Trade Solution (WITS) ${ }^{13}$ and the PTAs depth measures were calculated based on Mulabdic et al. (2017) using the contents of trade agreements from the World Bank database (Hofmann et al. 2016). Given the availability of tariff and trade data, this study is restricted to the period from 1996 to 2011.

\section{Methodology}

Because the core of production networks is regionally concentrated, in this work, we focus on the impacts that changes in the structural composition of parts and components suppliers have on Latin America's intra-bloc exports. For this empirical exercise, we use a model known as the workhorse of empirical international trade analysis: the gravity model (Baier and Bergstrand 2007). The gravity model is distinguished by its good fit and its parsimonious and tractable representation of economic interactions among many countries, also allowing for disaggregation of the trade in different levels of geographical organization and product classification (Anderson 2011).

To quantify the impact that changes in the structural composition of parts and components suppliers had on the development of the intra-bloc machinery trade, we follow the methodology proposed by Florensa et al. (2015), an augmented gravity model that accounts for the effect of the import of intermediate products. The adoption of such a framework is justified by the fact that, different from the standard gravity framework, this version accounts for the effect that the import of parts and

\footnotetext{
10 The list containing the 89 countries divided by regions is available in the Table 8 in "Appendix".

11 We use the PRODY measures calculated by Hausmann et al. (2007). According to the authors they "constructed the PRODY measure for a consistent sample of countries that reported trade data in each of the years 1999-2001. These indexes are the result of an average of 3 years" (Hausmann et al. 2007). Because the chosen years are previous to the Chinese accession to the World Trade Organization, the possibility of a downward bias in the ranking of the machinery goods (in particular, final goods, given the increase in multinationals assembling their final products China) is minimized.

${ }^{12}$ We thank an anonymous referee for suggesting the use of PTAs depth to implicitly control non-tariff barriers.

13 Tariff data were classified to HS six-digit level and when necessary was converted to the HS1992 version following the classification in Kimura and Obashi (2010).
} 
components of a given sector from a given supplier have on the Latin American intra-bloc exports. The proposed model assumes that in the first period, Latin American countries can import parts and components from any region of the world. These parts and components are employed to produce other parts and components that in a second period will be used domestically or traded with another country. Alternatively, they can be used to manufacture a final product that will be consumed domestically or traded with a third country. We assume that Latin American production networks are created when Latin American countries use parts and components imported from any region of the world to produce a final product or other parts and components that are exported to another Latin American country.

The Latin American intra-bloc trade of final products and parts and components in a given year is explained by the tariffs imposed by the importer country in the same year and the exporter country imports of parts and components in the previous year. We augment the Florensa et al. (2015) model to capture the possible effects of the non-tariff barriers by adding a PTA depth measure. The PTA depth index calculation follows Mulabdic et al. (2017): based on the content of the trade agreements database, we count the number of legally enforceable provisions covered by each agreement and normalize it between 0 and 1 .

Fixed-effect dummies are used to capture all sources of unobserved heterogeneity that are constant for each period of time, individual, and sector. Following Anderson and van Wincoop (2003, 2004), exporter-time and importer-time dummies are employed to control for the multilateral resistance, sector dummies control for unobserved heterogeneities of each machinery sector, while exporter-importer dummies are added to guard against unobserved heterogeneities on the relation of each country pair (Baier and Bergstrand 2007). The proposed models were defined as follows:

$$
\begin{aligned}
\ln \left(\mathrm{XF}_{i j k t}\right)= & \alpha_{0}+\sum_{r=1}^{7} \alpha_{r} \ln M \_\mathrm{pc}_{r i k t-1}+\alpha_{8} \ln \left(1+\operatorname{tarif} f_{j i k t}\right)+\alpha_{9} \ln \left(1+\operatorname{depth}_{i j t}\right) \\
& +\gamma_{i t}+\varphi_{j t}+s_{i j}+\omega_{k}+\varepsilon_{i j k t}, \\
\ln \left(\mathrm{XPC}_{i j k t}\right)= & \beta_{0}+\sum_{r=1}^{7} \beta_{r} \ln M \_\mathrm{pc}_{r i k t-1}+\beta_{8} \ln \left(1+\operatorname{tarif} f_{j i k t}\right)+\beta_{9} \ln \left(1+\operatorname{depth}_{i j t}\right) \\
& +n_{i t}+\tau_{j t}+z_{i j}+\mu_{k}+\delta_{i j k t},
\end{aligned}
$$

where $\mathrm{XF}_{i j k t}$ and $\mathrm{XPC}_{i j k t}$ denote the traded value of final products and parts and components from country $i$ to country $j$ (these countries are limited to Latin American countries only) of sector $k$ in year $t$. The traded values are explained by country $i$ 's imports of parts and components of sector $k$ from a given region $r$ in year $t-l\left(M_{-} \mathrm{pc}_{\text {rikt }-1}\right)$, the tariff imposed by the importing country $j$ over the product of sector $k$ provided by country $i$ in time $t$ tariff $_{j i k t}$, the depth measure of the PTA between country $i$ and $j$ in year $t$ depth $_{i j t}$, exporter-time and importer-time dummies (time is defined as a 5-year period), the sector and the importer-exporter dummies. 
One difference between this work and that of Florensa et al. (2015) is the definition of the object of study. As already mentioned, we selected a more specific object of study, focusing on the machinery industry alone. This allows us to use more disaggregated and detailed data, increasing the refinement of the parts and components and final products correspondence. Additionally, we can classify machinery industry products into four different sectors, decreasing the bias that can result from the use of aggregated data.

Based on previous works about production fragmentation and use of imported inputs, it is expected that the purchase of parts and components from another country should provide some efficiency gain or advantage to Latin American countries. Based on this fact, we expect that the increase in imports of parts and components from the East Asian region should guarantee a production gain for Latin American countries, increasing the intra-bloc machinery trade.

An important contribution of this paper is that the analysis is not limited to the quantity impact of the import of parts and components on the intra-bloc trade; we also propose a way of verifying quality changes. Since we know that there was a change in the shares of machinery parts and components providers, we attempt to evaluate if this variation also produced a modification in the Latin American intrabloc trade pattern. Once again, it is expected that if the East Asian region is more efficient in the production of machinery parts and components, providing inputs with higher quality and/or cheaper prices, Latin American countries should be able to diversify and improve the quality of their intra-bloc trade basket.

To check this hypothesis, we propose a substitution of the traded values by a trade basket sophistication index that is calculated based on the PRODY index developed in Hausmann et al. (2007). The PRODY index can be used as a proxy for the sophistication of the product, and according to Hausmann et al. (2007), countries that have an export basket more similar to the developed countries tend to register economic growth in the subsequent periods. Based on this concept and the importance of economic growth for the development of Latin American countries, we use the PRODY index to calculate the composition of the import basket of parts and components (IMPY index) and the intra-bloc export basket (EXPY index). The objective is to estimate if the imports of parts and components from specific regions contributed or not to bring the Latin American intra-bloc export basket closer to the developed countries. The proposed models are defined as follows:

$$
\begin{aligned}
\ln \left(\mathrm{EXPYF}_{i j k t}\right)= & \alpha_{0}+\sum_{r=1}^{7} \alpha_{r} \ln \mathrm{IMPY}_{-} \mathrm{pc}_{r i k t-1}+\alpha_{8} \ln \left(1+\operatorname{tariff}_{j i k t}\right) \\
& +\alpha_{9} \ln \left(1+\operatorname{depth}_{i j t}\right)+\gamma_{i t}+\varphi_{j t}+s_{i j}+\omega_{k}+\varepsilon_{i j k t}, \\
\ln \left(\mathrm{EXPYPC}_{i j k t}\right)= & \beta_{0}+\sum_{r=1}^{7} \beta_{r} \ln \mathrm{IMPY}_{-} \mathrm{pc}_{r i k t-1}+\beta_{8} \ln \left(1+\operatorname{tariff}_{j i k t}\right) \\
& +\beta_{9} \ln \left(1+\operatorname{depth}_{i j t}\right)+n_{i t}+\tau_{j t}+z_{i j}+\mu_{k}+\delta_{i j k t},
\end{aligned}
$$

where EXPYF Ejkt $_{i j}$ and EXPYPC $i j k t$ denote the EXPY index attributed to the basket of the final products and parts and components exported from country $i$ to country $j$ 
(these countries are limited to Latin American countries only) of sector $k$ in year $t$. The EXPY index is calculated as the weighted average of the PRODY index of each component of the basket of a given sector. The EXPY index attributed to the baskets of final products and parts and components traded inside Latin America is explained by the IMPY index attributed to the basket of parts and components of sector $k$ that country $i$ imported from a given region $r$ in year $t-1$ (IMPY_pc rikt-1 $_{\text {) }}$ ), the depth measure of the PTA between country $i$ and $j$ in year $t$ depth $_{i j t}$, the tariff imposed by the importing country $j$ over the product of sector $k$ provided by country $i$ in time $t$ $\operatorname{tariff}_{j i k t}$, the exporter-time and importer-time dummies (time is defined as a 5-year period), and the sector and the importer-exporter dummies.

\section{Results: quantity analysis}

A common characteristic of trade data is the existence of missing and zero trade values. As the natural logarithm of zero does not exist, the estimated regressions do not consider the zero trade values that are important information about the trade pattern. The dropped data are information not used in the estimation, possibly leading to a bias in the regression results. ${ }^{14}$ To avoid this problem, we estimate the regressions using the pseudo-Poisson maximum likelihood (PPML) method (Santos Silva and Tenreyro 2006). The PPML is the most accepted technique in the gravity model literature, allowing us to account for the observations with zero trade values. ${ }^{15}$ In addition, trade data are plagued by heteroscedasticity, consequently the use of OLS can lead to the estimation of biased elasticities (Santos Silva and Tenreyro 2006).

We first estimate Eqs. (2) and (3) for the values of the pooled machinery intrabloc exports. We also consider separate estimations for the main machinery sectors: electric machinery and transport equipment.

The first half of Table 3 contains the results for the intra-bloc exports of machinery final products. The tariff coefficient for the pooled data regression is negative and statistically significant, indicating that reductions in import tariffs of machinery final products are associated with increases in their intra-bloc exports. Consequently, the advance of the regional integration in Latin America through the decrease in the import tariffs imposed over the intra-bloc machinery trade have a positive impact on the development of Latin American machinery production networks. On the opposite side, the coefficient for PTA depth is statistically insignificant, showing that changes in non-tariff barriers do not affect production networks. The variables related to the origin of the imported parts and components reveal that an intensification of imports from the rest of the world (ROW), East Asia (EA), and Latin American (LA) countries, increase the intra-bloc trade of final products in the subsequent period. The results reveal that a $1 \%$ increase in imports

\footnotetext{
14 The share of dropped values when the OLS method is employed ranges from around 17-29\% of the total values estimated with the PPML technique.

15 In our database, we also have missing tariff and trade data for a given group of countries and products that affect the independent variables. Unfortunately, the PPML model cannot address this problem.
} 
Table 3 The effect of imports of machinery parts and components on Latin American intra-bloc machinery exports

\begin{tabular}{|c|c|c|c|c|c|c|}
\hline & \multicolumn{3}{|c|}{ Final products } & \multicolumn{3}{|c|}{ Parts and components } \\
\hline & $\begin{array}{l}\text { Pooled } \\
\text { machinery }\end{array}$ & $\begin{array}{l}\text { Electric } \\
\text { machinery }\end{array}$ & $\begin{array}{l}\text { Transport } \\
\text { equipment }\end{array}$ & $\begin{array}{l}\text { Pooled } \\
\text { machinery }\end{array}$ & $\begin{array}{l}\text { Electric } \\
\text { machinery }\end{array}$ & $\begin{array}{l}\text { Transport } \\
\text { equipment }\end{array}$ \\
\hline Tariff & $\begin{array}{c}-\mathbf{0 . 1 7} * * * \\
(0.05)\end{array}$ & $\begin{array}{c}-\mathbf{0 . 1 2} * * \\
(0.06)\end{array}$ & $\begin{array}{r}-0.05 \\
(0.08)\end{array}$ & $\begin{array}{r}-0.03 \\
(0.04)\end{array}$ & $\begin{array}{r}-0.03 \\
(0.04)\end{array}$ & $\begin{array}{r}-0.05 \\
(0.04)\end{array}$ \\
\hline $\begin{array}{l}\text { Lagged imports of parts } \\
\text { and components from } \\
\text { ROW }\end{array}$ & $\begin{array}{r}\mathbf{0 . 1 5} * * * \\
(0.05)\end{array}$ & $\begin{array}{c}-\mathbf{0 . 2 4} * * \\
(0.09)\end{array}$ & $\begin{array}{r}\mathbf{0 . 1 8} * * \\
(0.07)\end{array}$ & $\begin{array}{r}\mathbf{0 . 1 9} * * * * \\
(0.05)\end{array}$ & $\begin{array}{l}0.08 \\
\quad(0.07)\end{array}$ & $\begin{array}{l}0.04 \\
\quad(0.06)\end{array}$ \\
\hline $\begin{array}{l}\text { Lagged imports of parts } \\
\text { and components from } \\
\text { EU }\end{array}$ & $\begin{array}{r}-0.03 \\
(0.08)\end{array}$ & $\begin{array}{l}0.18 \\
\quad(0.23)\end{array}$ & $\begin{array}{r}-0.03 \\
(0.21)\end{array}$ & $\begin{array}{r}-0.20 \\
(0.13)\end{array}$ & $\begin{array}{c}-\mathbf{0 . 4 2} * * * \\
(0.12)\end{array}$ & $\begin{array}{r}-0.08 \\
(0.12)\end{array}$ \\
\hline $\begin{array}{l}\text { Lagged imports of parts } \\
\text { and components from } \\
\text { EA }\end{array}$ & $\begin{array}{r}\mathbf{0 . 4 5} * * * \\
(0.06)\end{array}$ & $\begin{array}{l}0.00 \\
\quad(0.15)\end{array}$ & $\begin{array}{l}0.15 \\
\quad(0.19)\end{array}$ & $\begin{array}{l}0.05 \\
\quad(0.07)\end{array}$ & $\begin{array}{c}\mathbf{0 . 3 8} * * * \\
(0.10)\end{array}$ & $\begin{array}{l}0.31 \\
\quad(0.20)\end{array}$ \\
\hline $\begin{array}{l}\text { Lagged imports of parts } \\
\text { and components from } \\
\text { LA }\end{array}$ & $\begin{array}{c}\mathbf{0 . 5 3} * * * \\
(0.08)\end{array}$ & $\begin{array}{l}0.07 \\
\quad(0.09)\end{array}$ & $\begin{array}{r}-0.12 \\
(0.18)\end{array}$ & $\begin{array}{c}\mathbf{0 . 6 4} * * * \\
(0.08)\end{array}$ & $\begin{array}{l}0.16 \\
\quad(0.11)\end{array}$ & $\begin{array}{r}\mathbf{0 . 3 9} * * * \\
(0.14)\end{array}$ \\
\hline $\begin{array}{l}\text { Lagged imports of parts } \\
\text { and components from } \\
\text { US and Canada }\end{array}$ & $\begin{array}{c}-\mathbf{0 . 3 2} * * * \\
(0.08)\end{array}$ & $\begin{array}{c}-\mathbf{0 . 5 2} * * * \\
(0.15)\end{array}$ & $\begin{array}{r}-0.32 \\
(0.23)\end{array}$ & $\begin{array}{c}\mathbf{0 . 3 1} * * * * \\
(0.08)\end{array}$ & $\begin{array}{c}-\mathbf{0 . 1 7} * \\
(0.09)\end{array}$ & $\begin{array}{c}-\mathbf{0 . 4 9} * * * \\
(0.18)\end{array}$ \\
\hline $\begin{array}{l}\text { Lagged imports of parts } \\
\text { and components from } \\
\text { China and HK }\end{array}$ & $\begin{array}{c}-\mathbf{0 . 2 7} * * * \\
(0.05)\end{array}$ & $\begin{array}{r}\mathbf{0 . 2 2} * * \\
(0.09)\end{array}$ & $\begin{array}{l}0.06 \\
\quad(0.10)\end{array}$ & $\begin{array}{r}-0.02 \\
(0.06)\end{array}$ & $\begin{array}{l}0.02 \\
\quad(0.10)\end{array}$ & $\begin{array}{l}0.02 \\
\quad(0.07)\end{array}$ \\
\hline PTA depth & $\begin{array}{r}-0.24 \\
(0.26)\end{array}$ & $\begin{array}{c}-\mathbf{0 . 6 6} * * * \\
(0.22)\end{array}$ & $\begin{array}{r}-0.20 \\
(0.65)\end{array}$ & $\begin{array}{r}-0.33 \\
(0.29)\end{array}$ & $\begin{array}{r}-0.09 \\
(0.20)\end{array}$ & $\begin{array}{l}0.03 \\
\quad(0.49)\end{array}$ \\
\hline Observations & 16,943 & 4320 & 4032 & 16,667 & 4256 & 3794 \\
\hline$R^{2}$ & 0.87 & 0.90 & 0.94 & 0.87 & 0.94 & 0.97 \\
\hline
\end{tabular}

Results that are statistically significant and different from zero are highlighted using bold text

Given a restriction of space, the coefficients of secondary variables are omitted. Robust standard errors in parentheses: $* p<0.10, * * p<0.05, * * * p<0.01$

of parts and components from LA leads to an increase of $0.53 \%$ in the intra-bloc exports of final products. The coefficient for imports from EA is also high, approximately $0.45 \%$, while imports from the ROW have a smaller effect, approximately $0.15 \%$. On the other hand, the coefficient of imports from the North America $^{16}$ and China are negative, indicating a decrease on the intra-bloc trade of final machinery products of 0.32 and $0.27 \%$, respectively. Although it is not possible to identify the exact reasons why imports from these suppliers do not stimulate intra-bloc trade, we consider a few hypotheses. The first is that an important share of imported parts and components are used in domestic production networks being consumed in the domestic market. Given the lack of data we cannot verify this hypothesis. A second possibility is that a share of these parts and

\footnotetext{
16 The term North America refers to US and Canada.
} 
components are used to produce goods exported to countries outside Latin America. This case is beyond the scope of this paper. It could also be the case that imports from these regions are used to produce parts and components that are exported to other Latin American countries. If that is the case, coefficients will be positive in the second half of the table, when dependent variables are parts and components exports.

Results in the second column refer to the electric machinery trade. The import tariff coefficient is negative, indicating that a decrease of $1 \%$ in the tariffs imposed on electric machinery parts and components imports, all ceteris paribus, stimulates an increase of $0.12 \%$ in intra-bloc exports of electric machinery final products. Once again, the coefficient for imports from North America is negative, indicating that a $1 \%$ increase in imports from this region causes a decrease in the intra-bloc exports of final electric machinery of $0.52 \%$. Imports from the ROW also have a negative impact of $0.24 \%$. On the opposite side, a $1 \%$ increase in imports of electric machinery parts and components from China promotes an intensification of $0.22 \%$ in the intra-bloc trade of final products. The PTA depth coefficient is statistically significant and indicates that deeper agreements lead to a decrease in the intraregional trade of electric machinery final products. According to Hofmann et al. (2016), agreements between developing countries are in general less deep and focus more on the decrease of import tariffs, since they are still high. ${ }^{17}$ This is in accordance with our findings that show that decreases in import tariffs are more efficient than deeper agreements in the promotion of intra-bloc electric machinery final products exports. Additionally, in Latin America shallow agreements embrace more members, while deeper ones are in general bilateral agreements involving Mexico and Central American countries. Consequently, members of shallower agreements, such as the Mercosur, promote higher trade flows among themselves than members of deeper agreements. Lastly, according to Baier and Bergstrand (2007), all PTAs are "phased-in" over time, approximately 5-10 years. Therefore, older and shallower agreements, implemented in the 1990s, should have bigger impacts than the deeper ones, the majority of which were implemented in 2009, only 2 years before the end of the period studied. ${ }^{18}$

With regard to transport equipment, the results are almost all statistically insignificant. The exception is the coefficient for imports from the ROW, indicating that a $1 \%$ increase in imports of transport equipment parts and components from this region leads to an increase of $0.18 \%$ in intra-bloc exports of final transport equipment.

The second half of Table 3 displays the intra-bloc parts and components export coefficients. In this case, import tariff and PTA depth coefficients are statistically insignificant, signaling an increase in regional integration through the decrease of the import tariffs or non-tariff barriers would not affect the production fragmentation and relocation inside Latin America. Imports of parts and components from

\footnotetext{
17 The mean of the import tariff between Latin American countries in the studied period was $6.89 \%$ for machinery final products and $5.64 \%$ for machinery parts and components. For the case of electric machinery, the average import tariffs are $9.92 \%$ for final products and $6.62 \%$ for parts and components.

18 Table 9 in the "Appendix" contains the list of PTAs in force during the studied period.
} 
LA, North America, and the ROW have positive and statistically significant coefficients. As observed in Florensa et al. (2015), imports of parts and components from these regions generate what they called a "complementary effect". In other words, they stimulate production fragmentation and its relocation inside Latin America, since parts and components imported by a Latin American country in the first period produce other parts and components that will be used in a third Latin American country, promoting these countries engagement in machinery productions networks. A $1 \%$ increase in parts and components imports from LA results in an increase of $0.64 \%$ of the intra-bloc export of parts and components. Imports from North America promote an increase of $0.31 \%$, while imports from the ROW have a smaller effect of $0.19 \%$.

In the specific case of electric machinery, imports from EA stimulate the intrabloc trade of parts and components with a coefficient of $0.39 \%$, while imports from European Union (EU) and North America have a negative effect. In the case of transport equipment, the LA coefficient is positive, while the North American one is negative. Florensa et al. (2015) refer to the situation when coefficients are negative as the "substitution effect", because instead of enhancing the development of production networks among Latin American countries, it promotes trade inside domestic markets or with countries in third regions.

Evidence indicates that increases in the import of parts and components from LA have the biggest positive impact in the creation of a Latin American machinery production network. This result aligns with Florensa et al. (2015) and the production fragmentation theory that states that the core of production networks is regionally organized. Imports from North America, a region that is geographically close to Latin America and known for engaging in back-and-forth intra-firm production network transactions with Mexico and Central American countries, presented mixed results. It stimulates the intra-bloc trade of machinery parts and components in general, but decreases the trade of final products. Conversely, the results indicate that in the specific case of electric machineries, imports from EA and China foment production fragmentation. This result also aligns with Florensa et al. (2015) and Fung et al. (2015b) who verified an increase of parts and components supplies from Asian countries supporting Latin America's engagement in production networks.

As mentioned in Sect. 2, Latin America is an area where economic integration still lags behind other regions of the globe. Although there are 21 different PTAs signed by LA countries, none of them integrates the whole region. Given this fact, we perform one extra exercise to explore the heterogeneity inside the region. Based on economic proximity and negotiated PTAs, we classified Latin America into three subregions: one composed of Argentina, Brazil, Paraguay, and Uruguay, who are members of Mercosur; a second composed of Bolivia, Colombia, Ecuador, Peru, and Venezuela who are members of the Andean Community (CAN); and a third with the members of Central America (Costa Rica, El Salvador, Guatemala, Honduras, Nicaragua, and Panama), Mexico and Chile. ${ }^{19}$

\footnotetext{
${ }^{19}$ Venezuela was classified as part of CAN, because during the majority of the studied period it was a member of it. Chile and Mexico were aggregated with Central American economies given the existence of many PTAs among them and because both countries are not members of either Mercosur or CAN.
} 
Table 4 The effect of imports of machinery parts and components on Latin American intra-bloc machinery exports by subregion

\begin{tabular}{|c|c|c|c|c|c|c|}
\hline & \multicolumn{3}{|c|}{ Final products } & \multicolumn{3}{|c|}{ Parts and components } \\
\hline & $\begin{array}{l}\text { CE, } \\
\text { Mexico } \\
\text { and Chile }\end{array}$ & $\begin{array}{l}\text { Andean } \\
\text { Community }\end{array}$ & Mercosur & $\begin{array}{l}\text { CE, } \\
\text { Mexico } \\
\text { and Chile }\end{array}$ & $\begin{array}{l}\text { Andean } \\
\text { Community }\end{array}$ & Mercosur \\
\hline Tariff & $\begin{array}{c}-\mathbf{0 . 2 8} * * * \\
(0.07)\end{array}$ & $0.06(0.09)$ & $\begin{array}{c}-\mathbf{0 . 2 3} * * * \\
(0.07)\end{array}$ & $\begin{array}{l}0.05 \\
\quad(0.08)\end{array}$ & $\begin{array}{r}-0.05 \\
(0.10)\end{array}$ & $\begin{array}{c}-\mathbf{0 . 1 0} * * * \\
(0.03)\end{array}$ \\
\hline $\begin{array}{l}\text { Lagged imports of } \\
\text { parts and } \\
\text { components from } \\
\text { ROW }\end{array}$ & $\begin{array}{l}0.04 \\
\quad(0.06)\end{array}$ & $\begin{array}{r}-0.13 \\
(0.09)\end{array}$ & $\begin{array}{r}\mathbf{0 . 1 5} * * \\
(0.07)\end{array}$ & $\begin{array}{r}\mathbf{0 . 2 3} * * * \\
(0.06)\end{array}$ & $\begin{array}{r}-0.14 \\
(0.12)\end{array}$ & $\begin{array}{r}\mathbf{0 . 1 0} * * \\
(0.05)\end{array}$ \\
\hline $\begin{array}{l}\text { Lagged imports of } \\
\text { parts and } \\
\text { components from } \\
\text { EU }\end{array}$ & $\begin{array}{r}-0.18 \\
(0.13)\end{array}$ & $\begin{array}{r}-0.18 \\
(0.25)\end{array}$ & $\begin{array}{l}0.12 \\
\quad(0.19)\end{array}$ & $\begin{array}{c}-\mathbf{0 . 4 5} * * * \\
(0.12)\end{array}$ & $\begin{array}{r}-0.17 \\
(0.20)\end{array}$ & $\begin{array}{r}-0.17 \\
(0.13)\end{array}$ \\
\hline $\begin{array}{l}\text { Lagged imports of } \\
\text { parts and } \\
\text { components from } \\
\text { EA }\end{array}$ & $\begin{array}{r}\mathbf{0 . 1 5} * * * \\
(0.06)\end{array}$ & $\begin{array}{r}\mathbf{0 . 3 6} * * \\
(0.17)\end{array}$ & $\begin{array}{c}\text { 0.66**** } \\
(0.13)\end{array}$ & $\begin{array}{r}\text { 0.25**** } \\
(0.08)\end{array}$ & $\begin{array}{r}-0.04 \\
(0.19)\end{array}$ & $\begin{array}{l}0.03 \\
\quad(0.09)\end{array}$ \\
\hline $\begin{array}{l}\text { Lagged imports of } \\
\text { parts and } \\
\text { components from } \\
\text { LA }\end{array}$ & $\begin{array}{r}\mathbf{0 . 3 2} * * * * \\
(0.09)\end{array}$ & $\begin{array}{r}\mathbf{0 . 4 9} * * * * \\
(0.13)\end{array}$ & $\begin{array}{l}0.10 \\
\quad(0.11)\end{array}$ & $\begin{array}{r}\mathbf{0 . 4 5} * * * * \\
(0.07)\end{array}$ & $0.16(0.12)$ & $\begin{array}{l}0.05 \\
\quad(0.09)\end{array}$ \\
\hline $\begin{array}{l}\text { Lagged imports of } \\
\text { parts and } \\
\text { components from } \\
\text { US and Canada }\end{array}$ & $\begin{array}{c}\mathbf{0 . 4 2} * * * \\
(0.10)\end{array}$ & $\begin{array}{r}-0.02 \\
(0.25)\end{array}$ & $\begin{array}{c}-\mathbf{0 . 9 2} * * * \\
(0.15)\end{array}$ & $\begin{array}{c}\mathbf{0 . 5 8} * * * \\
(0.10)\end{array}$ & $\begin{array}{l}\text { 0.40* } \\
\quad(0.21)\end{array}$ & $\begin{array}{c}-\mathbf{0 . 2 5} * * * \\
(0.09)\end{array}$ \\
\hline $\begin{array}{l}\text { Lagged imports of } \\
\text { parts and } \\
\text { components from } \\
\text { China and HK }\end{array}$ & $\begin{array}{c}-\mathbf{0 . 2 2} * * * \\
(0.05)\end{array}$ & $\begin{array}{c}-\mathbf{0 . 3 8} * * * * \\
(0.13)\end{array}$ & $\begin{array}{r}-0.12 \\
(0.09)\end{array}$ & $\begin{array}{l}0.06 \\
\quad(0.07)\end{array}$ & $0.13(0.11)$ & $\begin{array}{c}\mathbf{0 . 2 6} * * * * \\
(0.05)\end{array}$ \\
\hline PTA depth & $\begin{array}{c}-\mathbf{0 . 6 0} * * * \\
(0.22)\end{array}$ & $0.48(0.56)$ & $\begin{array}{l}0.66 \\
\quad(1.02)\end{array}$ & $\begin{array}{c}-\mathbf{1 . 2 9} * * * \\
(0.35)\end{array}$ & $\begin{array}{r}-0.06 \\
(0.31)\end{array}$ & $\begin{array}{l}1.03 \\
(0.85)\end{array}$ \\
\hline Observations & 0.71 & 0.69 & 0.91 & 0.90 & 0.73 & 0.92 \\
\hline$R^{2}$ & 7807 & 5104 & 4032 & 7635 & 5104 & 3928 \\
\hline
\end{tabular}

Results that are statistically significant and different from zero are highlighted using bold text Given a restriction of space, the coefficients of secondary variables are omitted. Robust standard errors in parentheses: $* p<0.10, * * p<0.05, * * * p<0.01$

Table 4 contains the results of machinery exports from each subregion. ${ }^{20}$ Given the reduction in the number of observations, we consider only the pooled machinery data results. The majority of the coefficients are statistically insignificant for the case of CAN exports. Indeed, among the three subregions, CAN is the one with the smallest machinery trade. The results reveal that imports from LA and EA countries enhance the intra-regional trade of final machinery by 0.5 and $0.36 \%$, while imports

${ }^{20}$ Once the regions were selected based on PTAs, the PTA depth was dropped from the regressions. 
from North America enhance the intra-regional trade of machineries parts and components by $0.4 \%$. In the cases of Central America, Mexico and Chile, we observe that imports from EA, LA and North America enhance the intra-regional trade of machinery final products by $0.15,0.32$, and $0.42 \%$, respectively. Imports from these three regions and the ROW enhance the regional trade of parts and components by $0.25,0.45,0.58$, and $0.23 \%$, respectively. On the opposite side, imports from China and EU have negative effects. The results indicate that production fragmentation in Central America, Mexico and Chile is stronger than in CAN, with EA, LA and North America, who, in ascending order, have been important suppliers for the regional production networks. Though composed of only four economies, Mercosur is responsible for the biggest intra-bloc machinery trade. The results also indicate that imports from the ROW and EA stimulate the exports of final products, while imports from the ROW and China enhance the exports of parts and components inside Latin America. Coefficients for EA and China are higher than the ROW: a $1 \%$ increase in import of parts and components from EA induced an increase of $0.66 \%$ in the intra-bloc trade of final products compared with $0.15 \%$ for imports from the ROW, while imports from China promoted a $0.26 \%$ increase in the intra-bloc trade of parts and components compared with $0.10 \%$ for imports from the ROW. On the opposite side, imports from North America do not stimulate the intra-bloc export of machinery.

We conclude that, different from Central American, Mexico and Chile, production networks promoted by Mercosur countries depend more on imports from China and EA, while imports from North America have a negative impact. In this case, it seems that geographical and economic proximity still play an important role, with North American imports fomenting the first regions' engagement in production fragmentation, while in Mercosur's case, a region more distant from North America, the imports from EA and China are more important.

\section{Results: quality analysis}

Considering the wide range of machinery products and that some are more sophisticated than the others, our next step is to examine which regions provide parts and components that promote Latin American production networks of products more similar to the ones produced by developed countries. Being involved in the manufacturing process of products with higher sophistication level instead of just buying the final product from other regions, Latin American countries gain access to technology, benefit from positive spillover effects, and increase the possibilities of enjoying economic growth.

The first half of Table 5 presents the results for the intra-bloc trade of final products, while results for the intra-bloc trade of machinery parts and components are in the second half. The first notable feature is that the tariff coefficient is positive in all columns, indicating that a decrease in the import tariff leads to a decrease in the sophistication of the machinery export basket. In other words, the export basket becomes more similar to the developing countries. One possible interpretation for this fact is that with higher tariffs, products with lower sophistication and lower 
Table 5 The effect of import composition of machinery parts and components on Latin American intrabloc machinery exports sophistication

\begin{tabular}{|c|c|c|c|c|c|c|}
\hline & \multicolumn{3}{|c|}{ Final products } & \multicolumn{3}{|c|}{ Parts and components } \\
\hline & $\begin{array}{l}\text { Pooled } \\
\text { machinery }\end{array}$ & $\begin{array}{l}\text { Electric } \\
\text { machinery }\end{array}$ & $\begin{array}{l}\text { Transport } \\
\text { equipment }\end{array}$ & $\begin{array}{l}\text { Pooled } \\
\text { machinery }\end{array}$ & $\begin{array}{l}\text { Electric } \\
\text { machinery }\end{array}$ & $\begin{array}{l}\text { Transport } \\
\text { equipment }\end{array}$ \\
\hline Tariff & $\begin{array}{c}\mathbf{0 . 0 5} * * * \\
(0.01)\end{array}$ & $\begin{array}{c}\mathbf{0 . 0 7} * * * \\
(0.01)\end{array}$ & $\begin{array}{c}\mathbf{0 . 0 5} * * * \\
(0.02)\end{array}$ & $\begin{array}{c}\mathbf{0 . 0 8} * * * \\
(0.01)\end{array}$ & $\begin{array}{r}\mathbf{0 . 0 8} * * * \\
(0.01)\end{array}$ & $\begin{array}{c}\mathbf{0 . 0 6} * * * \\
(0.02)\end{array}$ \\
\hline $\begin{array}{l}\text { Lagged imports of parts } \\
\text { and components from } \\
\text { ROW }\end{array}$ & $\begin{array}{r}\mathbf{0 . 0 1} * * \\
(0.01)\end{array}$ & $\begin{array}{l}0.02 \\
\quad(0.01)\end{array}$ & $\begin{array}{l}0.00 \\
\quad(0.01)\end{array}$ & $\begin{array}{c}\mathbf{0 . 0 4} * * * * \\
(0.01)\end{array}$ & $\begin{array}{l}0.01 \\
\quad(0.01)\end{array}$ & $\begin{array}{l}0.01 \\
\quad(0.01)\end{array}$ \\
\hline $\begin{array}{l}\text { Lagged imports of parts } \\
\text { and components from } \\
\text { EU }\end{array}$ & $\begin{array}{c}\mathbf{0 . 0 4} * * * \\
(0.01)\end{array}$ & $\begin{array}{l}\mathbf{0 . 0 4} * \\
\quad(0.02)\end{array}$ & $\begin{array}{l}0.03 \\
\quad(0.05)\end{array}$ & $\begin{array}{c}\mathbf{0 . 0 4} * * * \\
(0.01)\end{array}$ & $\begin{array}{r}-0.03 \\
(0.02)\end{array}$ & $\begin{array}{r}-0.01 \\
(0.05)\end{array}$ \\
\hline $\begin{array}{l}\text { Lagged imports of parts } \\
\text { and components from } \\
\text { EA }\end{array}$ & $\begin{array}{c}\mathbf{0 . 0 2} * * * \\
(0.01)\end{array}$ & $\begin{array}{l}0.03 \\
\quad(0.03)\end{array}$ & $\begin{array}{l}0.01 \\
\quad(0.04)\end{array}$ & $\begin{array}{c}\mathbf{0 . 0 4} * * * \\
(0.01)\end{array}$ & $\begin{array}{c}-\mathbf{0 . 0 4} * \\
(0.02)\end{array}$ & $\begin{array}{r}-0.03 \\
(0.03)\end{array}$ \\
\hline $\begin{array}{l}\text { Lagged imports of parts } \\
\text { and components from } \\
\text { LA }\end{array}$ & $\begin{array}{c}\mathbf{0 . 0 2} * * * \\
(0.01)\end{array}$ & $\begin{array}{r}\mathbf{0 . 0 6} * * \\
(0.03)\end{array}$ & $\begin{array}{r}-0.03 \\
(0.06)\end{array}$ & $\begin{array}{r}\mathbf{0 . 0 2} * * \\
(0.01)\end{array}$ & $\begin{array}{l}0.03 \\
\quad(0.03)\end{array}$ & $\begin{array}{l}0.00 \\
\quad(0.05)\end{array}$ \\
\hline $\begin{array}{l}\text { Lagged imports of parts } \\
\text { and components from } \\
\text { US and Canada }\end{array}$ & $\begin{array}{c}\mathbf{0 . 0 6} * * * * \\
(0.01)\end{array}$ & $\begin{array}{r}\mathbf{0 . 0 7} * * * * \\
(0.03)\end{array}$ & $\begin{array}{r}-0.02 \\
(0.04)\end{array}$ & $\begin{array}{r}\text { 0.10**** } \\
(0.01)\end{array}$ & $\begin{array}{r}-0.01 \\
(0.03)\end{array}$ & $\begin{array}{l}0.01 \\
\quad(0.04)\end{array}$ \\
\hline $\begin{array}{l}\text { Lagged imports of parts } \\
\text { and components from } \\
\text { China and HK }\end{array}$ & $\begin{array}{l}0.00 \\
\quad(0.01)\end{array}$ & $\begin{array}{l}0.03 \\
\quad(0.02)\end{array}$ & $\begin{array}{l}0.02 \\
\quad(0.01)\end{array}$ & $\begin{array}{l}0.01 \\
\quad(0.01)\end{array}$ & $\begin{array}{c}\mathbf{0 . 0 4} * * * \\
(0.02)\end{array}$ & $\begin{array}{l}0.00 \\
\quad(0.01)\end{array}$ \\
\hline PTA depth & $\begin{array}{l}0.01 \\
\quad(0.03)\end{array}$ & $\begin{array}{l}0.03 \\
\quad(0.05)\end{array}$ & $\begin{array}{l}0.04 \\
\quad(0.07)\end{array}$ & $\begin{array}{l}0.01 \\
\quad(0.04)\end{array}$ & $\begin{array}{c}-0.08 * \\
(0.05)\end{array}$ & $\begin{array}{l}0.07 \\
\quad(0.06)\end{array}$ \\
\hline Observations & 16,943 & 4320 & 4032 & 16,667 & 4256 & 3794 \\
\hline$R^{2}$ & 0.42 & 0.46 & 0.49 & 0.44 & 0.51 & 0.55 \\
\hline
\end{tabular}

Results that are statistically significant and different from zero are highlighted using bold text

Given a restriction of space, the coefficients of secondary variables are omitted. Robust standard errors in parentheses: $* p<0.10, * * p<0.05, * * * p<0.01$

values that are comparatively easier to be produced by developing countries were manufactured in most of the countries and were consumed in the domestic market, while machinery products with a higher level of sophistication were produced by just a few countries in the region and traded inside the bloc. The import tariff reduction allowed for an increase in the intra-bloc trade and specialization. This phenomenon promoted a faster growth in the trade of less sophisticated products than the sophisticated ones.

Considering parts and components suppliers, we verify that imports from the ROW, EU, EA, LA, and North America promoted an increase in the sophistication of the final products traded inside Latin America. A $1 \%$ increase in North American participation in the import basket composition, all ceteris paribus, promotes an increase of $0.06 \%$ in the quality of the intra-bloc export basket, while imports from EU promoted an increase of $0.04 \%$, followed by increases of $0.02 \%$ in the case of 
imports from LA or EA, and $0.01 \%$ for the ROW. The second column reveals that imports just from LA and North America had a positive effect in the electric machinery sector, while the coefficients for imports from other regions are statistically insignificant. Increases of $1 \%$ in imports from North America promote an increase of $0.07 \%$ in the quality of final electric machinery intra-bloc export basket, while imports from LA promote an increase of $0.06 \%$. Transport equipment coefficients were all statistically insignificant. In the second half of Table 5, we verify similar results for the case of pooled machinery data. North American imports promote an increase of $0.1 \%$ in the quality of the parts and components export basket, while imports from the EU and EA promote an increase of $0.04 \%$ each. In column 5, the coefficients are slightly different, revealing that imports only from China promote a $0.04 \%$ increase in the intra-bloc export basket of electric machinery parts and components, while imports from EA have a negative effect. Once again, transport equipment coefficients are statistically insignificant.

Results in this section partially support the hypothesis that an increase in imports of parts and components from Asian countries promotes an increase in the quality of the intra-bloc export basket. Nevertheless, imports from EU and North America had a bigger positive effect. Table 6 presents the PRODY mean of the import basket from each region in 1996 and 2011, revealing that import baskets from EU and North America were still composed of products with a high sophistication level. Given the increase in Asian product imports share in the detriment of imports from both regions, we can conclude that imports from EU and North America concentrated in higher sophistication products, while Asia supplied products with a slightly lower level of sophistication at very competitive prices. Another interesting feature is that, although the share of imports from the ROW is the smallest one, imports from this region are concentrated in products with a very high level of sophistication.

As in the previous section, we perform a similar exercise considering the exports of countries classified in three different subregions to explore their differences. Table 7 reveals that for Mexico, Chile, and Central American countries the imports

Table 6 Machinery imported parts and components PRODY index mean

\begin{tabular}{|c|c|c|c|c|c|c|c|c|}
\hline & \multicolumn{2}{|c|}{ Latin America } & \multicolumn{2}{|c|}{$\begin{array}{l}\text { CE, Mexico and } \\
\text { Chile }\end{array}$} & \multicolumn{2}{|c|}{$\begin{array}{l}\text { Andean } \\
\text { Community }\end{array}$} & \multicolumn{2}{|l|}{ Mercosur } \\
\hline & 1996 & 2011 & 1996 & 2011 & 1996 & 2011 & 1996 & 2011 \\
\hline ROW & $18,273.1$ & $18,358.7$ & $17,997.5$ & $18,005.2$ & $18,569.9$ & $18,808.3$ & $18,453.3$ & $18,503.4$ \\
\hline $\mathrm{EU}$ & $17,492.8$ & $17,652.7$ & $17,418.5$ & $17,327.4$ & $17,581.6$ & $18,067.0$ & $17,530.3$ & $17,785.3$ \\
\hline $\begin{array}{l}\text { North } \\
\text { America }\end{array}$ & $16,870.1$ & $17,576.7$ & $16,735.8$ & $17,245.1$ & $17,032.2$ & $17,577.7$ & $16,935.9$ & $18,238.5$ \\
\hline EA & $16,629.9$ & $17,106.3$ & $16,535.6$ & $16,930.5$ & $16,742.7$ & $17,258.1$ & $16,677.4$ & $17,268.1$ \\
\hline LA & $16,389.4$ & $16,313.9$ & $16,256.1$ & $15,845.9$ & $16,188.2$ & $16,486.5$ & $16,907.2$ & $17,034.1$ \\
\hline China & $15,109.2$ & $16,445.3$ & $15,589.5$ & $16,272.3$ & $15,006.5$ & $16,549.7$ & $14,276.8$ & $16,660.5$ \\
\hline
\end{tabular}

Source Author's calculation, using data available from Hausmann et al. (2007) 
Table 7 The effect of import composition of machinery parts and components on Latin American intrabloc machinery exports sophistication by subregion

\begin{tabular}{|c|c|c|c|c|c|c|}
\hline & \multicolumn{3}{|c|}{ Final products } & \multicolumn{3}{|c|}{ Parts and components } \\
\hline & $\begin{array}{l}\mathrm{CE}, \\
\text { Mexico } \\
\text { and Chile }\end{array}$ & $\begin{array}{l}\text { Andean } \\
\text { Community }\end{array}$ & Mercosur & $\begin{array}{l}\text { CE, } \\
\text { Mexico } \\
\text { and Chile }\end{array}$ & $\begin{array}{l}\text { Andean } \\
\text { Community }\end{array}$ & Mercosur \\
\hline Tariff & $\begin{array}{r}\mathbf{0 . 0 4} * * * * \\
(0.01)\end{array}$ & $0.01(0.02)$ & $\begin{array}{c}-\mathbf{0 . 2 4} * * * \\
(0.07)\end{array}$ & $\begin{array}{r}\mathbf{0 . 1 1} * * * \\
(0.01)\end{array}$ & $\begin{array}{r}\mathbf{0 . 0 4} * * \\
(0.02)\end{array}$ & $\begin{array}{l}0.02 \\
\quad(0.01)\end{array}$ \\
\hline $\begin{array}{l}\text { Lagged imports of } \\
\text { parts and } \\
\text { components from } \\
\text { ROW }\end{array}$ & $\begin{array}{c}\mathbf{0 . 0 2} * * * \\
(0.01)\end{array}$ & $\begin{array}{r}-0.01 \\
(0.01)\end{array}$ & $\begin{array}{r}\mathbf{0 . 1 4} * * \\
(0.06)\end{array}$ & $\begin{array}{r}\mathbf{0 . 0 4} * * * \\
(0.01)\end{array}$ & $\begin{array}{r}\mathbf{0 . 0 3} * * * \\
(0.01)\end{array}$ & $\begin{array}{c}\mathbf{0 . 0 7} * * * * \\
(0.01)\end{array}$ \\
\hline $\begin{array}{l}\text { Lagged imports of } \\
\text { parts and } \\
\text { components from } \\
\text { EU }\end{array}$ & $\begin{array}{c}\mathbf{0 . 0 4} * * * \\
(0.02)\end{array}$ & $\begin{array}{c}-\mathbf{0 . 0 8} * * \\
(0.04)\end{array}$ & $\begin{array}{r}-0.25 \\
(0.19)\end{array}$ & $\begin{array}{r}\mathbf{0 . 0 5} * * * \\
(0.02)\end{array}$ & $\begin{array}{c}-\mathbf{0 . 1 0} * * * \\
(0.04)\end{array}$ & $\begin{array}{r}-0.01 \\
(0.04)\end{array}$ \\
\hline $\begin{array}{l}\text { Lagged imports of } \\
\text { parts and } \\
\text { components from } \\
\text { EA }\end{array}$ & $\begin{array}{l}\mathbf{0 . 0 2} * \\
(0.01)\end{array}$ & $\begin{array}{l}\mathbf{0 . 0 4} * \\
\quad(0.02)\end{array}$ & $\begin{array}{c}\text { 0.39**** } \\
(0.14)\end{array}$ & $\begin{array}{r}\mathbf{0 . 0 4} * * * \\
(0.01)\end{array}$ & $\begin{array}{c}-\mathbf{0 . 0 7} * * * \\
(0.03)\end{array}$ & $\begin{array}{r}\mathbf{0 . 0 6} * * * * \\
(0.02)\end{array}$ \\
\hline $\begin{array}{l}\text { Lagged imports of } \\
\text { parts and } \\
\text { components from } \\
\text { LA }\end{array}$ & $\begin{array}{l}0.01 \\
\quad(0.01)\end{array}$ & $\begin{array}{r}-0.02 \\
(0.03)\end{array}$ & $\begin{array}{r}-0.13 \\
(0.12)\end{array}$ & $\begin{array}{c}-\mathbf{0 . 0 2} * * \\
(0.01)\end{array}$ & $\begin{array}{r}-0.02 \\
(0.03)\end{array}$ & $\begin{array}{l}0.01 \\
\quad(0.02)\end{array}$ \\
\hline $\begin{array}{l}\text { Lagged imports of } \\
\text { parts and } \\
\text { components from } \\
\text { US and Canada }\end{array}$ & $\begin{array}{c}-\mathbf{0 . 0 4} * \\
(0.02)\end{array}$ & $\begin{array}{r}\mathbf{0 . 1 3} * * \\
(0.06)\end{array}$ & $\begin{array}{c}-\mathbf{0 . 7 7} * * * \\
(0.14)\end{array}$ & $\begin{array}{c}-\mathbf{0 . 0 5} * \\
(0.03)\end{array}$ & $\begin{array}{r}-0.09 \\
(0.05)\end{array}$ & $\begin{array}{c}-\mathbf{0 . 0 8} * * * \\
(0.03)\end{array}$ \\
\hline $\begin{array}{l}\text { Lagged imports of } \\
\text { parts and } \\
\text { components from } \\
\text { China and HK }\end{array}$ & $\begin{array}{c}-\mathbf{0 . 0 4} * * * \\
(0.01)\end{array}$ & $\begin{array}{r}-0.02 \\
(0.02)\end{array}$ & $\begin{array}{r}-0.12 \\
(0.08)\end{array}$ & $\begin{array}{c}-\mathbf{0 . 0 4} * * * \\
(0.01)\end{array}$ & $\begin{array}{c}-\mathbf{0 . 0 8}^{* * * *} \\
(0.02)\end{array}$ & $\begin{array}{c}-\mathbf{0 . 0 3} * \\
(0.02)\end{array}$ \\
\hline PTA depth & $\begin{array}{l}0.06 \\
\quad(0.04)\end{array}$ & $\begin{array}{c}-\mathbf{0 . 1 4} * * \\
(0.06)\end{array}$ & $\begin{array}{l}0.56 \\
\quad(1.01)\end{array}$ & $\begin{array}{r}\mathbf{0 . 1 5} * * * \\
(0.05)\end{array}$ & $\begin{array}{r}-0.06 \\
(0.08)\end{array}$ & $\begin{array}{c}-\mathbf{0 . 2 4} * \\
(0.14)\end{array}$ \\
\hline Observations & 0.46 & 0.34 & 0.91 & 0.47 & 0.37 & 0.51 \\
\hline$R^{2}$ & 7807 & 5104 & 4032 & 7635 & 5104 & 3928 \\
\hline
\end{tabular}

Results that are statistically significant and different from zero are highlighted using bold text

Given a restriction of space, the coefficients of secondary variables are omitted. Robust standard errors in parentheses: $* p<0.10, * * p<0.05, * * * p<0.01$

from the ROW, EU, and EA promote an increase in the sophistication of the final products this region produced and exported inside LA. Conversely, imports from North America and China have a surprisingly negative effect. The pattern does not change even when intra-bloc exports of parts and components are considered. The only difference is that LA imports have a negative impact. Table 6 reveals that from 1996 to 2011 the PRODY mean of this subregion import basket decreased, justifying the negative coefficient. Finally, the depth index indicates an increase in 
the sophistication of the intra-bloc exports of parts and components. The PTA depth coefficient is positive and statistically significant only in this case comprising the Central American countries Chile and Mexico, a subregion with the deepest PTAs.

For the Andean Community members, imports of parts and components from EU have a negative impact, while imports from EA and North America increase the sophistication of the machinery final products they export inside Latin America. When intra-bloc exports of parts and components are considered, imports from the ROW assume a positive coefficient. Although Table 6 revealed no decrease in the PRODY mean from 1996 to 2011, after econometrically controlling all variables, the model reveals a negative effect on intra-bloc exports of parts and components in the cases of imports from China, EA and EU.

Increases in EA and the ROW participation in Mercosur's import basket composition have a positive impact on Mercosur members' exports of machinery final products and parts and components, while North American participation in the import basket have a negative impact.

These results indicated that depending on the subregion, the origin of the imports can have a positive or negative effect on the sophistication level of the machinery exports inside Latin America. In general, imports from EA and the ROW had positive effects, while imports from North America and China had negative impacts. However, when we consider all Latin American countries, we verify positive contributions from North American imports. The results indicate that in the case of imports from China, the effect on the intra-bloc exports sophistication level were not positive as expected, revealing that its exports to Latin America were still composed of cheaper and less sophisticated parts and components. The exception is in the specific case of electric machinery, where imports from China increased the sophistication of the intra-bloc exports of parts and components.

\section{Final considerations}

In this paper, we investigated how the changes in the structural composition of Latin America's suppliers of machinery parts and components affected the development of Latin American regional production networks. In our analysis, we considered a quantity and a quality dimension of the impact of these imports.

In the first part of the paper, the descriptive analysis indicated a growth in the import of parts and components from all regions of the world. However, we observed that the growth in imports from the East Asian region was higher, resulting in a change in the structural composition of the suppliers. Concomitant with this composition change, we also verified a modification in the sophistication level on the intra-bloc exports. In the second part of the paper, we proceeded with an econometric analysis to identify from which regions the import of parts and components contributed more to develop production networks inside Latin America and increase the sophistication level of the traded products. The quantity analysis provided evidence that Latin American production networks increased during the studied period, and they were fomented by import of machinery parts and components from the ROW, LA, EA, and North America. Imports of parts and components from LA had the biggest positive impact in 
the creation of a Latin American machinery production network, while imports from North America stimulated the intra-bloc trade of machinery parts and components in general, decreasing the trade in specific machinery sectors. The expected result that the increase in imports from EA and China fomented production networks inside Latin America was confirmed for the specific case of electric machineries. Conversely, imports of parts and components from North America did not stimulate the intra-bloc trade of machineries final products and parts and components for the two specific sectors analyzed.

Exploring subregional heterogeneities, we identified that imports from North America had the highest positive impact in intra-bloc exports in the cases of the exports from Central America, Chile and Mexico subregions, as well as the Andean Community. Imports from EA and China had the highest positive effects in the case of exports from Mercosur countries. It is possible that geographical and economic proximity played an important role in this result, with North American imports fomenting the first two regions' engagement in production fragmentation, while imports from EA and China were more important for Mercosur members.

Considering the second dimension studied, the sophistication of the products traded in Latin America's regional production networks, the results provided evidence that partially supported the hypothesis that increases in imports of parts and components from Asian countries promote an increase in the quality of the intra-bloc export basket. The EA coefficient was positive for the pooled machinery data in Latin America and almost all subregions, while imports from China increased the sophistication of intrabloc exports of electric machinery parts and components. The coefficients for subregional pooled machinery data imports from China were negative, revealing that its exports to Latin America were still composed of cheaper and less sophisticated parts and components. The results from imports from North America were mixed, with negative coefficients in the subregional cases and positive coefficients when all Latin American countries were analyzed.

The findings of this paper indicate that Latin American governments should consider the possibility of being more proactive in the development of regional policies to facilitate the import and use of machinery parts and components. The heterogeneity between subregions indicates that countries from Mercosur could benefit more from imports from the EA and China to foment the expansion of regional production networks and the increase in the sophistication level of the machinery products traded inside Latin America, while North America appears as a natural and better option for the other countries. Moreover, Latin American countries could take advantage of the internalization of some machinery production steps to engage in machinery production networks and decrease the imports of machinery final products from third regions. These initial policies can proportionate economic growth and other positive spillover effects. In the medium and long term, these strategies could help Latin American countries overcome the lack of competitiveness in given machinery products and enhance the region's participation in the international machinery trade.

Acknowledgements I deeply appreciate the valuable comments from professors Fukunari Kimura, Kozo Kiyota, Toshihiro Okubo, Colin McKenzie, Masao Ogaki, and Yoshimasa Shirai from Keio University. I 
am thankful for the support from Professor Laura Márquez-Ramos and Juan Nelson Martínez Dahbura. I gratefully acknowledge the Keio University Doctorate Student Grant-in-Aid Program, the MEXTsupported Program for the Strategic Research Foundation at Private Universities, and Keio Economic Society for the financial support in part for this study. The analysis and results presented in this research are only the responsibility of the author.

Open Access This article is distributed under the terms of the Creative Commons Attribution 4.0 International License (http://creativecommons.org/licenses/by/4.0/), which permits unrestricted use, distribution, and reproduction in any medium, provided you give appropriate credit to the original author(s) and the source, provide a link to the Creative Commons license, and indicate if changes were made.

\section{Appendix}

See Tables 8 and 9.

Table 8 Country list by regions

\begin{tabular}{ll}
\hline Region & Name \\
\hline North America & Canada \\
North America & USA \\
China & China \\
China & China, Hong Kong \\
EA & Australia \\
EA & India \\
EA & Indonesia \\
EA & Japan \\
EA & Malaysia \\
EA & New Zealand \\
EA & Philippines \\
EA & Republic of Korea \\
EA & Singapore \\
EA & Thailand \\
EU & Austria \\
EU & Bulgaria \\
EU & Czech Republic \\
EU & Cyprus \\
EU & Denmark \\
EU & Estonia \\
EU & Finland \\
EU & France \\
EU & Germany \\
EU & Greece \\
EU & Hungary \\
EU & Ireland \\
EU & Italy \\
\hline & \\
EA & \\
EA & \\
EA & \\
EA &
\end{tabular}


Table 8 continued

\begin{tabular}{|c|c|}
\hline Region & Name \\
\hline $\mathrm{EU}$ & Latvia \\
\hline $\mathrm{EU}$ & Lithuania \\
\hline $\mathrm{EU}$ & Malta \\
\hline $\mathrm{EU}$ & The Netherlands \\
\hline $\mathrm{EU}$ & Poland \\
\hline $\mathrm{EU}$ & Portugal \\
\hline $\mathrm{EU}$ & Romania \\
\hline $\mathrm{EU}$ & Slovakia \\
\hline $\mathrm{EU}$ & Slovenia \\
\hline $\mathrm{EU}$ & Spain \\
\hline $\mathrm{EU}$ & Sweden \\
\hline $\mathrm{EU}$ & UK \\
\hline LA & Argentina \\
\hline LA & Bolivia \\
\hline LA & Brazil \\
\hline LA & Chile \\
\hline LA & Colombia \\
\hline LA & Costa Rica \\
\hline LA & Ecuador \\
\hline LA & El Salvador \\
\hline LA & Guatemala \\
\hline LA & Honduras \\
\hline LA & Mexico \\
\hline LA & Nicaragua \\
\hline LA & Panama \\
\hline LA & Paraguay \\
\hline LA & Peru \\
\hline LA & Uruguay \\
\hline LA & Venezuela \\
\hline ROW & Albania \\
\hline ROW & Algeria \\
\hline ROW & Azerbaijan \\
\hline ROW & Cameroon \\
\hline ROW & Cote d'Ivoire \\
\hline ROW & Croatia \\
\hline ROW & Egypt \\
\hline ROW & Georgia \\
\hline ROW & Ghana \\
\hline ROW & Iceland \\
\hline ROW & Israel \\
\hline ROW & Jamaica \\
\hline ROW & Kyrgyzstan \\
\hline ROW & Mali \\
\hline
\end{tabular}


Table 8 continued

\begin{tabular}{|c|c|}
\hline Region & Name \\
\hline ROW & Mauritius \\
\hline ROW & Morocco \\
\hline ROW & Niger \\
\hline ROW & Nigeria \\
\hline ROW & Norway \\
\hline ROW & Oman \\
\hline ROW & Republic of Moldova \\
\hline ROW & Russian \\
\hline ROW & Saudi Arabia \\
\hline ROW & Senegal \\
\hline ROW & Sudan \\
\hline ROW & Switzerland \\
\hline ROW & Republic of Macedonia \\
\hline ROW & Tunisia \\
\hline ROW & Turkey \\
\hline ROW & Uganda \\
\hline ROW & Ukraine \\
\hline ROW & Tanzania \\
\hline ROW & Zambia \\
\hline
\end{tabular}

Table 9 List of Latin American preferential trade agreements

\begin{tabular}{llll}
\hline Agreement & $\begin{array}{l}\text { Year that } \\
\text { entered } \\
\text { in force }\end{array}$ & Type & $\begin{array}{l}\text { Number of } \\
\text { enforceable } \\
\text { provisions }\end{array}$ \\
\hline Panama-Chile & 2008 & FTA and EIA & 12 \\
CAN & 1988 & CU & 15 \\
Chile-Costa Rica & 2002 & FTA and EIA & 16 \\
MERCOSUR & 1991 & CU and EIA & 17 \\
Central American Common Market & 1961 & CU & 18 \\
$\quad$ CACM) & 2008 & FTA and EIA & 18 \\
Chile-Honduras & 2010 & FTA and EIA & 18 \\
Chile-Guatemala & 2002 & FTA and EIA & 19 \\
Chile-El Salvador & 2006 & FTA and EIA & 19 \\
CAFTA-DR & 2004 & FTA and EIA & 21 \\
Mexico-Uruguay & 2003 & FTA and EIA & 22 \\
Panama-El Salvador & 2008 & FTA and EIA & 22 \\
Panama-Costa Rica & 2009 & FTA and EIA & 22 \\
Colombia-Northern Triangle & 2009 & FTA and EIA & 22 \\
Panama-Guatemala & 2009 & FTA and EIA & 22 \\
Panama-Honduras & 2009 & FTA and EIA & 22 \\
Peru-Chile & &
\end{tabular}


Table 9 continued

\begin{tabular}{llll}
\hline Agreement & $\begin{array}{l}\text { Year that } \\
\text { entered } \\
\text { in force }\end{array}$ & Type & $\begin{array}{l}\text { Number of } \\
\text { enforceable } \\
\text { provisions }\end{array}$ \\
\hline Chile-Mexico & 1999 & FTA and EIA & 24 \\
El Salvador-Honduras & 2008 & FTA and EIA & 24 \\
Panama-Nicaragua & 2009 & FTA and EIA & 24 \\
Chile-Colombia & 2009 & FTA and EIA & 25 \\
Colombia-Mexico & 1995 & FTA and EIA & 27 \\
\hline
\end{tabular}

\section{References}

Aminian N, Fung KC, Ng F (2009) A comparative analysis of trade and economic integration in East Asia and Latin America. Econ Change Restruct 42:105-137

Amiti M, Konings J (2007) Trade liberalization, intermediate inputs and productivity. Am Econ Rev 97:1611-1638

Anderson JE (2011) The gravity model. Ann Rev Econ 3:133-160

Anderson JE, van Wincoop E (2003) Gravity with gravitas: a solution to the border puzzle. Am Econ Rev 93(1):170-192

Anderson JE, van Wincoop E (2004) Trade Costs. J Econ Lit 42(3):691-751

Ando M, Kimura F (2005) The formation of international production and distribution networks in East Asia. In: Ito T, Rose AK (eds) International trade in East Asia. University of Chicago Press, Chicago

Ando M, Kimura F (2013a) Evolution of machinery production networks: linkage of North America with East Asia. ERIA Discussion Paper Series DP-2013-32, Economics Research Institute for ASEAN and East Asia (ERIA)

Ando M, Kimura F (2013b) Production linkage of Asia and Europe via Central and Eastern Europe. J Econ Integr 28:204-240

Athukorala P (2005) Product fragmentation and trade patterns in East Asia. Asian Econ Papers 4(3):1-27

Athukorala P, Yamashita N (2006) Product fragmentation and trade integration: East Asia in a global context. N Am J Econ Finance 17(3):233-256

Baier SL, Bergstrand JH (2007) Do Free Trade Agreements Actually Increase Members' International Trade? J Intern Econ 71(1):72-95

Baldwin R, Lopez-Gonzalez J (2015) Supply-chain trade: a portrait of global patterns and several testable hypothesis. World Econ 38(11):1682-1721

Calfat G, Cassimon D, Flôres RG Jr, Rivas A (2011) Far from champions, close to midgets-international production sharing in Central and South America. Rev de Econ y Estad 49:101-137

Curran L, Zignago S (2013) Regional integration of trade in South America: how far has it progressed and in which sectors? Int Trade J 27(1):3-35

Florensa LM, Márquez-Ramos L, Martínez-Zarzoso I, Recalde ML (2015) Regional versus global production networks: where does Latin America stand? Appl Econ 47(37):3938-3956

Fung KC, Garcia-Herrero A, Siu A (2015a) Production sharing in Latin America and East Asia. Working Papers 0901, BBVA Bank, Economic Research Department

Fung KC, Hwang HC, Ng F, Seade J (2015b) Production networks and international trade: China, Brazil, and Mexico. N Am J Econ Finance 34:421-429

Goldberg P, Khandelwal A, Pavcnik N, Topalova P (2009) Trade liberalization and new imported inputs. Am Econ Rev Papers Proc 99(2):494-500

Goldberg P, Khandelwal A, Pavcnik N, Topalova P (2010) Trade imported intermediate inputs and domestic product growth: evidence from India. Q J Econ 125(4):1727-1767

Grossman GM, Rossi-Hansberg E (2008) Trading tasks: a simple theory of offshoring. Am Econ Rev 98(5):1978-1997

Harrigan J, Venables AJ (2004) Timeliness, trade and agglomeration. CEPR Discussion Paper, No, p 4294

Hausmann R, Hwang J, Rodrik D (2007) What you export matters. J Econ Growth 12(1):1-15 
Hofmann C, Osnago A, Ruta M (2016) Horizontal depth: a new database on the content of deep agreements. Mimeo, The World Bank

Hummels D, Klenow PJ (2005) The variety and quality of a nation's exports. Am Econ Rev 95(3):704-723

Jones R, Kierzkowski H (2005) International fragmentation and the new economic geography. N Am J Econ Finance 16:1-10

Kehoe TJ, Ruhl KJ (2013) How important is the new goods margin in international trade? J Political Econ 121(2):358-392

Kimura F, Obashi A (2010) International production networks in machinery industries: structure and its evolution. Working Papers DP-2010- 09, Economics Research Institute for ASEAN and East Asia (ERIA)

Kimura F, Takahashi Y, Hayakawa K (2007) Fragmentation and parts and components trade: comparison between East Asia and Europe. N Am J Econ Finance 18(1):23-40

Moreira MM, Blyde JS, Martincus CV, Molina D (2013) Too far to export: domestic transport costs and regional export disparities in Latin America and the Caribbean. IDB, Washington, DC

Mulabdic A, Osnago A, Ruta M (2017) Deep integration and UK-EU trade relations. World Bank Policy Research Working Paper No. 7947

Ng F, Yeats A (2003) Major Trade Trends in East Asia : What are their Implications for Regional Cooperation and Growth? World Bank Policy Research Working Paper No. 3084. https://doi.org/10. 1596/1813-9450-3084

Obashi A, Kimura F (2016) Deepening and Widening of Production Networks in ASEAN. ERIA Discussion Paper Series DP-2016-09, Economics Research Institute for ASEAN and East Asia (ERIA)

Organization for Economic Co-operation and Development (OECD) (2013) Interconnected economies: benefiting from global value chains. OECD Publishing, Paris

Santos Silva JMC, Tenreyro S (2006) The Log of Gravity. Rev Econ Stat 88(4):641-658

Timmer M, Dietzenbacher E, Los B, Stehrer R, de Vries G (2015) An illustrated user guide to the world input-output database: the case of global automotive production. Rev Int Econ 23(3):575-605

Yamashita N, Kohpaiboon A (2011). Trade in Supply Chains between ASEAN and China: Development and Implications. In: Findlay C (ed) ASEAN+1 FTAs and Global Value Chains in East Asia. ERIA Research Project Report 2010-29. ERIA, Jakarta, pp 25-51

Yokota K (2008) Parts and Components trade and Production Networks in East Asia - A Panel Gravity Approach. In: Hiratsuka D, Uchida Y (eds) Vertical Specialization and Economic Integration in East Asia. Institute of Developing Economies JETRO 